\title{
Métodos geofísicos integrados para a caracterização hidrogeológica dos aquíferos da microbacia Andes, Bebedouro, em São Paulo
}

\author{
Ivan Mamede Carlos ${ }^{1}$, Vagner Roberto Elis ${ }^{2 *}$, Renato Luiz Prado ${ }^{2}$ Jorge Luis Porsani ${ }^{2}$
}

\begin{abstract}
Resumo Este trabalho apresenta os resultados de uma investigação geofísica integrada a dados de poços tubulares para o estudo das características hidrogeológicas das Formações Adamantina e Serra Geral, em uma microbacia no distrito de Andes, em Bebedouro, no estado de São Paulo. Essa área foi alvo de estudos devido à intensa exploração de água subterrânea para uso agrícola e a sua possível relação com o aumento da atividade sísmica local. Neste trabalho foram utilizados métodos geofísicos e informações de poços tubulares, de maneira integrada, para buscar conhecimento mais detalhado das unidades geológicas que compõem os aquíferos, bem como de algumas de suas propriedades físicas. Os resultados mostram que a metodologia foi eficiente no imageamento das formações geológicas, no estudo da geometria dos aquíferos e na identificação de estruturas geológicas. Uma estimativa das propriedades hidrodinâmicas de aquíferos granulares pode ser feita pela determinação dos parâmetros de Dar Zarrouk e pela correlação com dados obtidos em testes de bombeamento. No presente trabalho, foi possível estabelecer uma correlação linear entre a resistência transversal e a transmissividade, porém com algumas limitações, devido à maior parte dos poços disponíveis serem perfurados também no basalto. Esse procedimento pode ser usado para auxiliar no gerenciamento do aquífero, tanto sob o ponto de vista da exploração como no de preservação.
\end{abstract}

Palavras-chave: métodos geofísicos; poços tubulares; Formação Adamantina; Formação Serra Geral; estudo de aquíferos.

\begin{abstract}
Integrated geophysical methods in the hydrogeological characterization of the Microbasin Andes, Bebedouro, São Paulo State. This paper presents the results of a geophysical survey integrated to well data for studying hydrogeological characteristics of Adamantina and Serra Geral Formations in a microbasin in the Andes District, in Bebedouro, state of São Paulo, Brazil. This area was the focus of studies due to the intense exploitation of groundwater for agricultural use and its relation with the increase of local seismic activity. In this paper, geophysical methods and well information were used, in an integrated way, to get more detailed knowledge of the aquifers and their physical properties. The results show that the approach was effective in imaging geological formations and their geometry study, as well as in the identification of geological structures. An estimation of hydrodynamic properties of granular aquifers can be done by the parameters of Dar Zarrouk and their correlation with data obtained from pumping tests. In this study, it was possible to establish a linear correlation between the transmissivity and transverse resistance, however with some limitations, because the majority of wells were drilled also in volcanic rocks. This procedure can be used to assist the aquifer management, under the aspects of exploration and preservation.
\end{abstract}

Keywords: geophysical methods; wells; Adamantina Formation; Serra Geral Formation; aquifer study.

\section{INTRODUÇÃO A água subterrânea tem im-} portância fundamental para a sociedade moderna. É impossível manter o fornecimento de água doce de qualidade para o abastecimento humano, a indústria e a agricultura se a mesma não for aproveitada (Unesco 2003). É frequentemente a mais viável alternativa de suprimento de água, especialmente onde a água de superfície sofreu processos de degradação pela ocupação antrópica. Consequentemente, o uso sustentável, a conservação cuidadosa das áreas de recarga e a proteção dos aquíferos contra a poluição são de grande importância.

Dessa forma, em razão da importância da água subterrânea, é necessário o desenvolvimento de metodologias capazes de melhorar o nível de conhecimento sobre os aquíferos e seu comportamento frente às ações exploratórias e degradantes impostas pelo desenvolvimento desordenado. Para a definição das políticas de gerenciamento de recursos hídricos, é preciso conhecer as características hidrogeológicas

\footnotetext{
${ }^{1}$ Instituto de Astronomia, Geofísica e Ciências Atmosféricas, Departamento de Geofísica, Programa de Pós-graduação em Geofísica, Universidade de São Paulo - USP, São Paulo (SP), Brasil. E-mail: imamede@gmail.com

${ }^{2}$ Instituto de Astronomia, Geofísica e Ciências Atmosféricas, Departamento de Geofísica, Universidade de São Paulo - USP, São

Paulo (SP), Brasil. E-mail: vagnelis@iag.usp.br, renato@iag.usp.br, porsani@iag.usp.br

*Autor correspondente
} 
do aquífero. O uso de métodos geofísicos aliados e parametrizados por informações de poços tubulares possibilita a coleta de informações sobre os parâmetros importantes do aquífero (como geometria, presença de estruturas, estimativa da transmissividade), com uma grande cobertura em área e a custos baixos. Dentro deste contexto está o desenvolvimento da Geofísica Aplicada à Hidrogeologia, área de atuação que merece especial atenção de pesquisadores do mundo todo, sendo atualmente denominada de Hidrogeofísica (Rubin \& Hubbard 2005). Uma abordagem que tem mostrado bons resultados é a integração de métodos geofísicos, como o uso de sondagens elétricas verticais e sondagens magnetotelúricas no estudo da geometria de aquíferos (Osella et al. 1999) e o de sondagens elétricas e de ressonância magnética no estudo de características hidrogeológicas (Vouillamoz et al. 2007).

Neste trabalho são apresentados resultados da aplicação conjunta de métodos geofísicos (geoelétricos e sísmicos), integrados a informações de poços tubulares, para o mapeamento de unidades hidrogeológicas e para estimativa de parâmetros hidrogeológicos do Aquífero Adamantina. O conjunto de informações possibilitou o estudo de várias características do aquífero, tais como: a geometria e o sentido do fluxo no aquífero superior, o topo do basalto, a estimativa da base do basalto em contato com a Formação Botucatu, a identificação de estruturas no interior do basalto, além da estimativa dos parâmetros hidrogeológicos. Essas informações são de grande importância para orientar a exploração responsável dos recursos hídricos subterrâneos na região.

ÁREA DE ESTUDO A área de estudo é uma microbacia localizada no distrito de Andes, município de Bebedouro, em São Paulo, dentro da Unidade de Gerenciamento de Recursos Hídricos 15, correspondente à Bacia do Turvo/Grande (Fig. 1). O clima, segundo Figueiredo et al. (2002), utilizando a classificação de climática de Köppen, é do tipo Cwa (subtropical com inverno moderado e seco, verão quente e chuvoso), com temperatura média máxima de $28,8^{\circ} \mathrm{C}$, média mínima $18,3^{\circ} \mathrm{C}$ e temperatura média de $23,5^{\circ} \mathrm{C}$. A precipitação média anual é de cerca de $1.400 \mathrm{~mm}$. O período de maior pluviosidade concentra-se entre outubro e

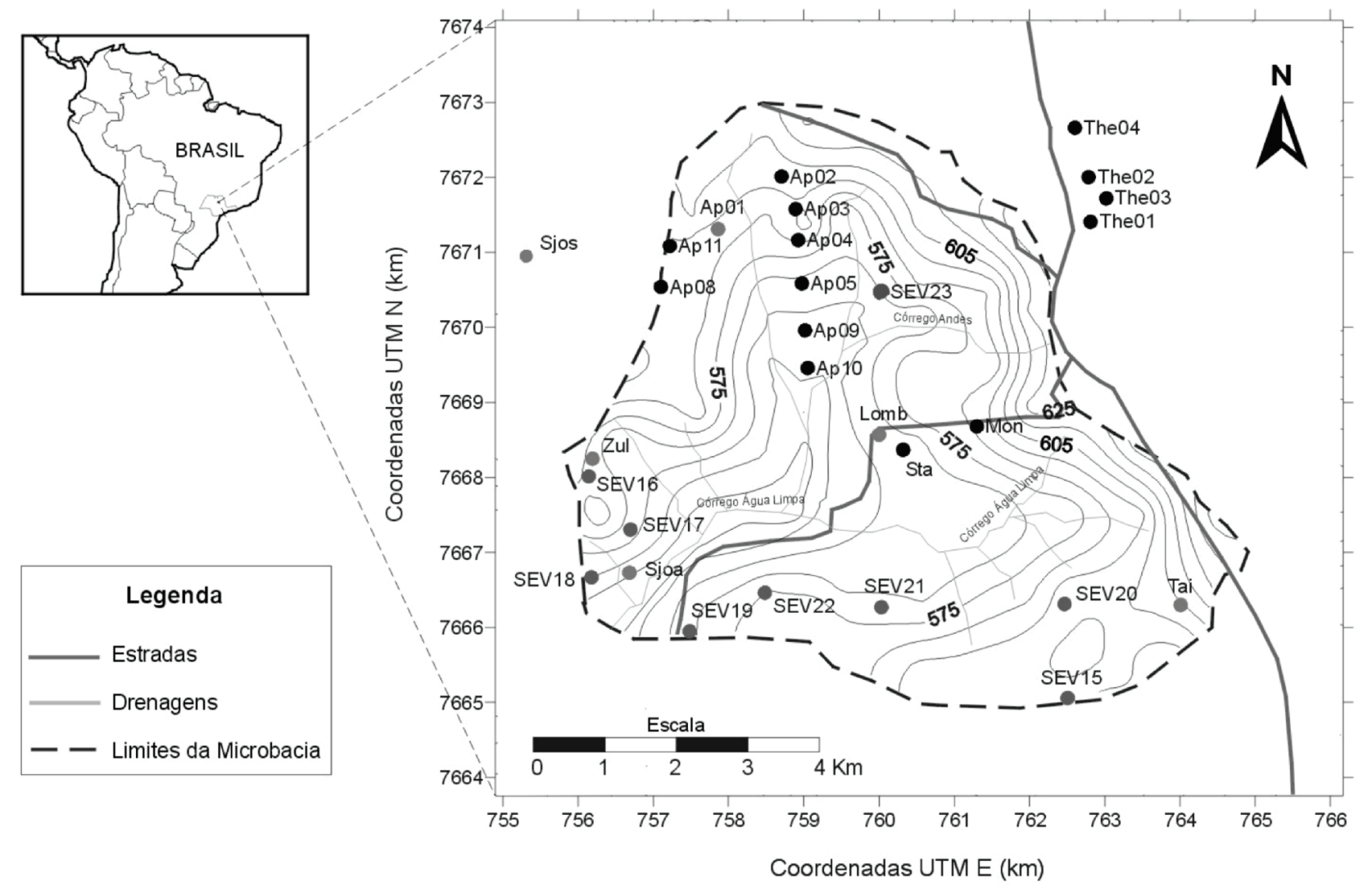

Figura 1 - Mapa topográfico da microbacia Andes (linha tracejada) em Bebedouro, São Paulo, com a localização das SEVS. Ap: Fazenda Aparecida; Sta: Fazenda Santa Ana; Mon1: Fazenda Monideni; The: Fazenda Santa Therezinha; Sjos: Fazenda São José; Zul: Fazenda Zulmira; Sjoa: Fazenda São João; Lomb: Fazenda Lombardo; Tai: Fazenda Tauiva. 
abril, sobretudo no verão, que acontece de dezembro a março. Com a falta de chuva no período de estiagem, a utilização da água subterrânea torna-se inevitável, principalmente para a irrigação das lavouras da região.

O crescimento e a modernização da agroindústria nos anos 1990, especialmente da laranja, e o consequente aumento da demanda por água para irrigação têm levado a um aumento da captação de água subterrânea. Por esta razão, associada ao crescimento demográfico, a demanda por água cresceu exponencialmente, sendo que o aumento do número de poços já tem causado mudanças no aquífero, com a observação de rebaixamento do nível estático em poços mais antigos. Acompanhado desse processo, o modo de ocupação da terra ocorre de forma pouco organizada, de maneira que as fragilidades e potencialidades dos ambientes naturais não são respeitadas, limitando-se, por vezes, o uso do recurso em condições satisfatórias.

Aspectos geológicos e hidrogeológicos $\mathrm{O}$ município de Bebedouro encontra-se na área de afloramento do Grupo Bauru (Cretáceo Superior). Várias divisões estratigráficas têm sido propostas ao longo dos anos para esse grupo. Fernandes (1992) e Fernandes \& Coimbra (2000) apresentam novas concepções sobre gênese e relações estratigráficas das unidades do Grupo Bauru, contrapondo-se à versão operacional clássica de Soares et al. (1980). Nesta concepção, a formação Caiuá tem status de Grupo, e a Adamantina é denominada de Formação Vale do Rio do Peixe. De acordo com Silva et al. (2005), no estado de São Paulo, o Grupo Bauru é representado pelas formações Caiuá, Pirapozinho, Santo Anastácio, Birigui, Araçatuba, Adamantina e Marília.

Para os objetivos deste trabalho, será utilizada a mesma classificação de Silva et al. (2005), de acordo com a concepção de Soares et al. (1980), sendo a Formação Adamantina a unidade aflorante na área de estudo.

A Formação Adamantina é constituída por um conjunto de fácies, cuja principal característica é a presença dos bancos de arenitos de granulação de fina a muito fina, cor de róseo a castanho, portando estratificação cruzada, alternados com bancos de lamitos, siltitos e arenitos lamíticos, de cor castanho-avermelhado à cinza castanho, maciços ou com acamamento plano-paralelo grosso, frequentemente com marcas de onda à microestratificação cruzada. São comuns a ocorrência de seixos de argilito da própria unidade, cimento e nódulos carbonáticos. O contato inferior da Formação Adamantina normalmente acontece com as formações mais antigas do Grupo Bauru, ou diretamente com o basalto Serra Geral, como é o caso da área de estudos. A espessura da Formação Adamantina varia de 50 a $135 \mathrm{~m}$ nos poços existentes na área. Considerando o aspecto hidrogeológico, o Aquífero Adamantina fornece, em geral, baixos valores hidrodinâmicos, tendo sua produtividade relacionada à espessura das camadas arenosas atravessadas. Isto ocorre devido a sua constituição litológica, na qual bancos de arenitos intercalam-se com aqueles de siltitos ou arenitos lamíticos. Suas principais características hidrodinâmicas são vazões de 5 a $50 \mathrm{~m}^{3} / \mathrm{h}$, vazões específicas de 0,5 a $3 \mathrm{~m}^{3} / \mathrm{h} / \mathrm{m}$ e transmissividade de 10 a $100 \mathrm{~m}^{2} /$ dia (IPT 2001).

Embora os basaltos da Formação Serra Geral não aflorem na área, são de grande importância hidrogeológica, devido à ocorrência em profundidades de poucas centenas de metros aliada à baixa produtividade do aquífero Adamantina. Da análise do material disponível sobre os poços existentes cadastrados nos escritórios do Departamento de Águas e Energia Elétrica (DAEE) de Araraquara e de Ribeirão Preto, nota-se que muitos poços (mais de 50\%) exploram também o Aquífero Serra Geral, sendo perfurados vários metros dentro do basalto. Os basaltos da Formação Serra Geral constituem um aquífero de extensão regional, porém com condições aquíferas restritas, definidas em função de descontinuidades (juntas, fraturas e falhas) e/ou pela presença de pacotes de arenitos interderrames (IPT 1981). Apresentam espessuras variáveis de 100 a $1.200 \mathrm{~m}$, sendo mais espessos no sentido do Rio Paraná. As transmissividades extremamente baixas na direção vertical, aliadas a sua grande espessura, condicionam os basaltos como o substrato hidrogeológico do Aquífero Bauru e a camada confinante do Botucatu subjacente. Como o fluxo das águas subterrâneas ocorre essencialmente nas fraturas da rocha, as quais são usualmente descontínuas, os parâmetros hidráulicos do aquífero (transmissividade, permeabilidade e porosidade) não possuem o mesmo significado que nos granulares, não servindo, de acordo com o IPT (2001), para previsões de disponibilidade hídrica. DAEE (1976) relatou a presença de grupos de transmissividades muito baixas (1 a $\left.9 \mathrm{~m}^{2} / \mathrm{d}\right)$ ou muito altas (100 a $200 \mathrm{~m}^{2} / \mathrm{d}$ ) na área estudada, com porosidade efetiva entre 1 e $5 \%$ e vazões extremamente variáveis. 
MÉTODOS GEOFÍSICOS Por meio dos métodos geofisicos utilizados neste trabalho, procurou-se avaliar características importantes para o estudo hidrogeológico. Dessa forma, foram realizados os seguintes ensaios:

- sondagens elétricas verticais (resistividade e polarização induzida, com arranjo Schlumberger) para estudar o perfil estratigráfico, profundidade da zona saturada, espessura do arenito, profundidade do topo e da base do basalto e obtenção dos valores de resistência transversal;

- caminhamento elétrico (resistividade, com arranjo dipolo-dipolo) para imageamento contínuo de perfis para mapear as unidades geológicas e as possíveis estruturas (falhas e fraturas);

- sondagens TDEM (Time Domain Electromagnetic) para estudar o perfil estratigráfico e as estruturas dentro do basalto (fraturas horizontais e possíveis arenitos intertrapianos e/ou zonas interderrames);

- sísmica de refração para imageamento das unidades geológicas.

Método da eletrorresistividade

Este método geofísico utiliza uma corrente elétrica artificial $I$, que é introduzida no terreno por meio de dois eletrodos (denominados de A e B), com o objetivo de medir a diferença de potencial $\Delta V$ gerado em outros dois eletrodos (denominados de $\mathrm{M}$ e $\mathrm{N}$ ) nas proximidades do fluxo de corrente elétrica, permitindo-se, assim, calcular a resistividade $\rho$ em subsuperfície, por meio da equação (1) (Orellana 1972):

$$
\mathrm{p}=K \cdot \frac{\Delta V}{I}(\text { ohm..m) }
$$

sendo $K$ um fator geométrico que depende das posições dos eletrodos no terreno e pode ser calculado para qualquer arranjo por meio da fórmula geral equação (2):

$$
K=\frac{2 \pi}{(1 / A M)-(1 / A N)-(1 / B M)+(1 / B N)}
$$

A variedade das técnicas de aplicação de ensaios (caminhamento ou perfil elétrico e sondagem, por exemplo), que possibilitam a investigação no sentido vertical (sondagem elétrica) ou lateral (caminhamento elétrico), e uma variedade ainda maior de arranjos de campo (Schlumberger, Wenner, dipolo-dipolo, polo-dipolo, Lee, entre outros) conferem ao método uma versatilidade muito grande.

Neste trabalho, o arranjo de campo, utilizado para os ensaios de sondagem elétrica vertical (SEV), foi denominado Schlumberger, que utiliza os quatro eletrodos dispostos no terreno de acordo com um mesmo alinhamento. A principal característica desse arranjo é que a distância MN deve ser bastante pequena em relação a $A B$, procurando sempre satisfazer a relação $\mathrm{MN} \leq \mathrm{AB} / 5$. A interpretação das curvas de SEV foi realizada por meio de softwares específicos, a partir da inversão dos dados geoelétricos, usando regressão em cadeia.

Os ensaios de SEV para estudar a Formação Adamantina e o topo do basalto foram realizados com o resistivímetro Syscal R2 Plus, da Iris Instruments, França, de $250 \mathrm{~W}$ de potência. Sondagens profundas, com aberturas de AB até $3.000 \mathrm{~m}$, que objetivaram identificar a base do basalto sobre a Formação Botucatu, foram realizadas com um transmissor VIP 5.000 de $5 \mathrm{~kW}$ de potência e um receptor digital Elrec Pro, da Iris Instruments.

A técnica de caminhamento elétrico se baseia na análise e na interpretação dos valores de resistividade aparente, obtidos a partir das medidas efetuadas na superfície do terreno, investigando, ao longo de uma seção, sua variação na horizontal, a uma ou mais profundidades determinadas. $\mathrm{O}$ arranjo de campo utilizado para os ensaios de caminhamento elétrico foi o dipolo-dipolo. Neste, o estudo da variação lateral do parâmetro físico pode ser efetuado em vários níveis teóricos de profundidades de investigação, obtendo-se uma caracterização dos materiais, em subsuperfície, tanto horizontal quanto verticalmente.

Atualmente, existem técnicas de interpretação quantitativa, as quais possibilitam a criação de mode$\operatorname{los} 2 \mathrm{D}$ com a distribuição espacial de camadas, corpos e estruturas com diferentes resistividades existentes no perfil estudado. Neste trabalho, utilizou-se o software RES2Dinv (Loke 2003), que determina automaticamente um modelo bidimensional de resistividade para o meio, por meio dos dados elétricos de campo. Os erros entre os dados de campo e os sintéticos gerados pelo programa são minimizados, e o modelo obtido a partir do ajuste dos dados observados e calculados é considerado como representativo das variações de resistividade do local. 
Os ensaios de caminhamento elétrico foram realizados com o sistema VIP 5.000 de $5 \mathrm{~kW}$ de potência e Elrec Pro, da Iris Instruments. Para esses ensaios, utilizou-se o espaçamento de $50 \mathrm{~m}$ entre os eletrodos, com cinco níveis de investigação.

O método da eletrorresistividade pode ser aplicado no sentido de buscar estudar as relações entre os parâmetros geofísicos e hidrogeológicos. Nesse caso, o método de correlação se fundamenta a partir de analogias existentes entre as equações que regem o movimento da água subterrânea, por meio de um meio permeável e da corrente elétrica em um meio condutor. Esse procedimento permite relacionar as propriedades elétricas e hidrodinâmicas dos materiais geológicos com uma geométrica comum, a espessura das camadas de um aquífero. Essa relação é feita com os chamados parâmetros de Dar Zarrouk (Maillet 1947). Com isso, a partir de medidas geoelétricas feitas em superfície, pode-se estimar as características hidrodinâmicas de um aquífero granular.

Os parâmetros de Dar Zarrouk permitem a interpretação e o entendimento do modelo geoelétrico de um meio com condutores estratificados (Orellana 1972). São relacionados a diferentes combinações de espessuras e resistividades de cada estrato geoelétrico do modelo. Para uma sequência de n camadas homogêneas e isotrópicas de resistividades $\rho$ i e espessuras Ei, os parâmetros de Dar Zarrouk são a resistência transversal e a condutância longitudinal. Esses parâmetros foram definidos por Maillet (1947) e receberam os símbolos $\mathrm{T}$ e $\mathrm{S}$, respectivamente. Para não serem confundidos com os parâmetros hidrodinâmicos, neste texto receberão os símbolos $R_{T}$ e $C_{L}$. A resistência transversal (resistividade multiplicada pela espessura da camada) pode ser correlacionada com a transmissividade (condutividade hidráulica multiplicada pela espessura da camada). Os primeiros trabalhos que utilizaram os parâmetros de Dar Zarrouk em pesquisas hidrogeológicas tiveram início no final da década de 1960 e início da década de 1970 (Kelly 1977).

Muitos autores, como Niwas \& Singhal (1981), Kosinsky \& Kelly (1981), Frohlich \& Kelly (1985), estudaram relações entre a transmissividade e a resistência transversal para aquíferos granulares. $\mathrm{O}$ estudo da relação entre a resistência transversal com a transmissividade obtida em testes de produção de poços tubulares permite relacionar as propriedades físicas elétricas e hidrodinâmicas dos materiais geológicos com uma propriedade geométrica comum, a espessura das camadas de um aquífero. Com isso, uma vez estabelecida uma correlação para determinada área, a partir de medidas geoelétricas feitas em superfície, pode-se estimar as características hidrodinâmicas de um aquífero granular em locais onde não existem poços. Mazac et al. (1985) propuseram um modelo hidrogeofísico geral para as propriedades elétricas e hidráulicas de aquíferos granulares e sintetizaram vários trabalhos, os quais mostraram uma relação direta entre a resistência transversal e a transmissividade.

Dessa forma, para aquíferos granulares pode-se estabelecer uma relação empírica entre os parâmetros de Dar Zarrouk e os hidrodinâmicos. Esta foi uma das propostas deste trabalho e, embora as características da área de estudo (exploração de água também do aquífero basalto fraturado) não tenham sido as mais favoráveis, a relação foi obtida e considerada satisfatória pela comparação com dados da literatura para estudos no Grupo Bauru (DAEE 1976, IPT 2001).

\section{Método da polarização induzida A polariza-} ção induzida (IP) é um fenômeno elétrico estimulado por corrente elétrica, observado como resposta retardada à voltagem, em materiais naturais (Sumner 1976). No método de IP - domínio do tempo, ao se aplicar uma corrente constante ao terreno, tem-se como resposta uma diferença de potencial $\Delta V$ primária. Durante o fluxo de corrente, ocorre uma polarização do terreno. A diferença de potencial primária $(\Delta V p)$ não se estabelece e nem se anula instantaneamente quando a corrente é emitida e cortada em pulsos sucessivos. Varia com o tempo na forma de uma curva $\Delta V_{I P}=f(t)$. A amplitude de um valor $\Delta V_{I P}(t)$ está diretamente ligada à maior ou menor capacidade que os materiais geológicos têm de se polarizarem, constituindo-se, portanto, na base do método. Essa capacidade de polarização constitui a suscetibilidade da IP dos materiais da Terra. O parâmetro medido é chamado de cargabilidade $(M)$ e pode ser expresso em milissegundos ou milivolt/Volt ( $\mathrm{mV} / \mathrm{V})$, como observado na equação (3):

$$
M=\frac{1}{\Delta V_{P}} \int_{t_{1}}^{t_{2}} \Delta V_{I P}(t) d t(\mathrm{mV} / \mathrm{V})
$$

As medidas de IP, normalmente, são realizadas de forma muito semelhante às de resistividade aparente, podendo-se analisar as diferenças 
de polarizabilidade do meio físico no sentido vertical (Sondagem IP), como também no horizontal a profundidades constantes (Caminhamento IP), utilizando os mesmos arranjos do método da resistividade. Neste trabalho, o procedimento foi a aplicação de sondagens de IP com medidas no domínio do tempo, sendo utilizado o resistivímetro Syscal R2 Plus, da Iris Instruments. Os ensaios foram executados com tempo de integração de dois segundos e tempo de atraso (delay time) de 200 milissegundos.

\section{Método eletromagnético no domínio do tempo}

O método eletromagnético no domínio do tempo (Time Domain Electromagnetics - TDEM) é um método indutivo que difere dos clássicos EM na aquisição de dados. No caso do TDEM, o campo secundário é medido na ausência do primário, isto é, a diferença fundamental entre o TDEM em relação aos outros é justamente o fato dele operar no domínio do tempo, ao passo que os outros operam no da frequência.

No método TDEM, o campo primário é um campo estacionário que é gerado fazendo-se passar uma corrente contínua numa bobina transmissora. O campo primário, por ser estacionário, não induz correntes no subsolo. Quando se corta a corrente no transmissor, o campo primário não decai instantaneamente a zero, mas varia rapidamente, gerando correntes no subsolo que originam um campo magnético (secundário), o qual tende a cancelar a variação (diminuição) do campo primário. A distribuição das correntes elétricas induzidas no subsolo assemelha-se a um sistema de correntes circulares paralelas à superfície do terreno que se difunde pelo terreno, atingindo profundidades maiores com o passar do tempo. Assim, a informação obtida nos instantes imediatamente a seguir ao corte da corrente (early times) está influenciada pelas estruturas mais superficiais do terreno, ao passo que, aquela obtida para tempos maiores (late times) diz respeito às mais profundas. Analisando-se o comportamento do campo magnético observado no receptor ao longo de um certo intervalo de tempo, foi possível obter-se informação sobre a estrutura geoelétrica do terreno. $\mathrm{O}$ campo para os tempos finais, também chamado de fase final, é sensível às variações de condutividade do terreno, o que tem grande interesse prático. Nos receptores TDEM, o que se registra é a variação de voltagem com o tempo, que cai para zero, porém as curvas obtidas para diferentes modelos geoelétricos são parecidas e difíceis de estudar. A alternativa utilizada é calcular as resistividades aparentes, frequentemente para a fase final. A resistividade aparente pode ser calculada pela equação (4):

$$
\rho_{a}=\left(\frac{M_{R} n \mu}{20 V}\right)^{2 / 3} \frac{\mu}{\pi} t^{-5 / 3} \text { (ohm.m) }
$$

onde,

$$
\begin{aligned}
& M_{R} \text { é o momento receptor; } \\
& n \text { o número de espiras do receptor; } \\
& \text { m a permeabilidade magnética; } \\
& t \text { o tempo desde o início do decaimento; } \\
& V \text { a voltagem e } \\
& r \text { o raio do loop transmissor. }
\end{aligned}
$$

Os equipamentos são compostos de um sistema de transmissão (um transmissor ligado a uma bobina pequena ou um loop quadrado de 20 a $150 \mathrm{~m}$ de lado) e um de recepção (um receptor ligado a uma bobina). Neste trabalho, utilizou-se o equipamento PROTEM, composto de receptor Protem Receiver e do transmissor Protem TEM47, fabricados pelo Geonics, do Canadá. De acordo com Mcneil (1990), são utilizados basicamente dois arranjos de campo: o primeiro é denominado de modo Slingram ou loop-loop, no qual duas pequenas bobinas (transmissora e receptora) são movidas juntas na linha de ensaio, tal como no método eletromagnético indutivo. $\mathrm{O}$ segundo arranjo é o modo central loop de sondagem, em que a bobina de recepção fica posicionada no centro de um loop quadrado estendido no terreno, o mesmo utilizado neste projeto.

Os dados fornecidos no ensaio TDEM (resistividade em função do tempo) foram interpretados como modelos de camadas com o software de inversão IX1D v 3.0 (Interpex 2007).

Método sísmico de refração Os métodos sísmicos se baseiam no fato de que as velocidades e trajetórias das ondas elásticas variam em função das mudanças nas propriedades elásticas dos solos e das rochas. O registro na superfície do terreno das frentes de ondas, que sofreram refração ou reflexão nas interfaces geológicas e apresentam contrastes nas propriedades elásticas, permite o mapeamento do subsolo. 
As análises dos tempos de percurso da onda entre o momento de sua geração (tiro sísmico) e seus registros em diferentes receptores permitem o cálculo das velocidades da onda nos meios investigados e as profundidades das interfaces que geraram refrações ou reflexões. Além do princípio físico envolvido, os métodos sísmicos de refração e reflexão se diferem na forma de aquisição dos dados e nos processos de interpretação (Telford et al. 1990).

A inversão dos dados obtidos com a sísmica de refração para a obtenção da imagem de subsuperfície pode ser feita por meio dos métodos recíproco ou tomográfico. Cada método tem suas vantagens e desvantagens, de forma que a escolha deve levar em conta as características do meio geológico investigado. A precisão do método recíproco, por exemplo, depende de situações geológicas relativamente simples, ou seja, camadas quase plano-paralelas, pouca variação lateral de velocidades e modelos de velocidade relativamente simples, com significativo contraste de velocidades entre as camadas geológicas. Como na região em estudo essas condições não são satisfeitas (observou-se importantes variações laterais de velocidade), escolheu-se o método tomográfico.

No método tomográfico, a inversão dos tempos de chegada é feita com algoritmos iterativos. A partir de um modelo inicial do campo de velocidades sísmicas e considerando o arranjo de campo empregado, analisam-se as diferenças entre os tempos de percurso calculados e os observados, visando ao aperfeiçoamento do modelo.

Neste trabalho, utilizou-se o aplicativo Rayfract (Intelligent Resources Inc. 2006), no modo de inversão suave, que gera um modelo inicial com gradiente constante. O método tomográfico utilizado pelo programa é o wavepath eikonal traveltime (WET), que, a partir do modelo inicial, calcula os tempos de percurso com um algoritmo baseado na equação iconal de primeira ordem, proposta por Lecomte et al. (2000), e na aproximação de volume Fresnel proposta por Watanabe et al. (1999). O modelo é aperfeiçoado para reduzir os resíduos entre os tempos calculados e os medidos. Tem-se como produto final uma seção que mostra a variação de velocidade com a profundidade.

A aquisição foi realizada com um sismógrafo GEODE Geometrics, utilizando-se 96 geofones de $14 \mathrm{~Hz}$, igualmente espaçados de $2 \mathrm{~m}$. Como fonte geradora de ondas, utilizou-se do impacto de uma marreta sobre placa metálica. Os pontos de tiro foram posicionados externamente ao arranjo (a 50 e a $2 \mathrm{~m}$ do primeiro e último geofones), e internamente a cada intervalo de 6 geofones (12 m), num total de 19 pontos de tiro.

\section{DISCUSSÃO}

Geometria Os ensaios de SEV associados a dados de poços possibilitaram o estudo da geometria do aquífero na parte Norte da área (Fig. 1). Na parte Sul, os ensaios sísmicos e as SEVs foram integrados, já que existia uma carência de poços. Esses procedimentos possibilitaram um refinamento da interpretação geofísica, a partir da qual foi possível gerar mapas de fluxo do aquífero superior, mapa de espessura do arenito e mapa do topo do basalto.

Foram realizados 23 ensaios de SEVs, com arranjo Schlumberger e abertura $\mathrm{AB} / 2$ máxima de $500 \mathrm{~m}$. Também foram efetuados quatro ensaios com abertura máxima de $3.000 \mathrm{~m}$, aqui denominados de SEVs longas, que serão discutidos mais tarde. As curvas de campo obtidas nas SEVs são típicas para o Grupo Bauru. Em geral, com quatro ou cinco camadas das quais pode-se definir três estratos geoelétricos. O primeiro como sendo a zona não saturada (solo superficial + zona de capilaridade), o segundo representando a zona saturada (arenito) - ambos os estratos fazendo parte da Formação Adamantina - e, por fim, os basaltos da Formação Serra Geral, como o terceiro estrato geoelétrico.

A interpretação quantitativa de SEVs normalmente é dificultada pelo princípio de equivalência, no qual um mesmo conjunto de dados admite o ajuste de vários modelos com diferentes combinações de resistividades e espessuras das camadas. Os software de inversão possibilitam realizar uma análise de equivalência, gerando-se um conjunto de modelos equivalentes nos quais pode-se identificar as camadas bem definidas e aquelas que apresentam maior variabilidade dos parâmetros. Dessa forma, para refinar a interpretação e diminuir possíveis problemas devido à ambiguidade nos modelos geoelétricos, alguns cuidados foram tomados: foi utilizado o software RESIXIP (Interpex 1993), o qual possibilita a análise de equivalência, auxiliando na escolha do melhor modelo geoelétrico para cada SEV. Como algumas SEVs foram realizadas junto a poços tubulares, escolheu-se o modelo que melhor se ajustou à profundidade do 
basalto dada pela informação dos poços mais próximos. Dessa forma, foi possível reduzir a ambiguidade das soluções especialmente na parte Norte. Na Tab. 1 pode-se observar as profundidades do topo da Formação Serra Geral, adquiridas nos poços da região por meio do DAEE do Estado de São Paulo.

Na Fig. 2 é apresentada a SEV AP02, em que pode-se observar o modelo geoelétrico com os valores obtidos de resistividade e cargabilidade, os modelos equivalentes com erro de ajuste inferior a $10 \% \mathrm{e}$ o perfil interpretado. Como pode ser observado na figura, existe uma grande variabilidade em quase todos os parâmetros, com exceção da resistividade e cargabilidade do arenito saturado. $\mathrm{O}$ modelo que melhor se ajusta à profundidade do basalto no local foi o escolhido, que, nesse caso, coincidiu com aquele com menor erro de ajuste.

Na Fig. 3 encontra-se um perfil nas proximidades da Fazenda Aparecida, que foi obtido com informações dos poços tubulares $2,3,4,5,9$ e $10 \mathrm{e}$ com as SEVs executadas próximas a esses poços.

Para a parte Sul, em razão da carência de poços, na interpretação das SEVs com a análise de equivalência, utilizou-se o modelo médio com menor erro de ajuste. No conjunto de modelos equivalentes, observou-se que, para a maioria deles, o topo do basalto era uma interface bem definida, com variação inferior a $5 \mathrm{~m}$ entre os modelos equivalentes. Para ilustrar isso, na Fig. 4 é apresentado o resultado da SEV20, que praticamente não apresentou variação para o topo do basalto entre os modelos. Pode-se observar também que a resistividade do sedimento saturado é bem definida. As camadas superiores (zona não saturada) já admitem modelos mais discrepantes. Isso pode ser explicado pelo contraste de resistividade pouco marcante observado na curva em sua parte inicial, que possibilita várias combinações de resistividades e espessuras equivalentes para as camadas superiores.

Na Fig. 5 são apresentados os modelos da SEV18, que apresentou a maior variação entre os modelos para o topo do basalto, na ordem de $30 \mathrm{~m}$. Por outro lado, observa-se que as resistividades são relativamente bem definidas. Nesse caso, ao contrário da SEV 20, pode-se observar que a curva mostra inflexões bem evidentes, em razão dos grandes contrastes entre as resistividades das camadas. Já para o topo do basalto, como existe certa dispersão dos pontos a partir de abertura $\mathrm{AB} / 2$ de $80 \mathrm{~m}$, essa interface admite maior variabilidade em sua profundidade.

As seções sísmicas, denominadas de SR01 a SR04, foram realizadas em quatro locais (Fig. 6), de acordo com a proposta do trabalho e a disponibilidade de espaço físico para os ensaios. A seção SR01 foi realizada ao lado dos poços 09 e 10 da Fazenda Aparecida, com o objetivo de caracterizar a velocidade da onda P no topo do basalto. Os sismogramas relativos aos tiros dados nas extremidades do arranjo de geofones (tiros direto e reverso) da linha SR03 são apresentados na Fig. 7. Esses sismogramas

Tabela 1 - Profundidade total do poço e do basalto, obtidas dos poços tubulares fornecidos pelo DAEE

\begin{tabular}{lccc} 
& Poço & $\begin{array}{c}\text { Profundidade } \\
\text { total }(\mathrm{m})\end{array}$ & \multicolumn{2}{c}{ Perfil estratigráfico } \\
\cline { 2 - 4 } & 90 & Formação Adamantina $(\mathrm{m})$ & Formação Serra Geral (m) \\
\hline Ap01 & 220 & 0 a 90 & - \\
Ap02 & 196 & 0 a 106 & 102 a 220 \\
Ap03 & 228 & 0 a 94 & 106 a 196 \\
Ap04 & 180 & 0 a 86 & 94 a 228 \\
Ap05 & 192 & 0 a 95 & 86 a 180 \\
Ap08 & 157 & 0 a 61 & 95 a 192 \\
Ap09 & 117 & 0 a 70 & 61 a 157 \\
Ap10 & 190 & 0 a 112 & 70 a 117 \\
Ap11 & 70 & 0 a 70 & 112 a 190 \\
Lom & 63 & 0 a 63 & - \\
Mon & 75 & 0 a 74 & - \\
Sjoa & 64 & 0 a 64 & 74 a 75 \\
Sjos & 170 & 0 a 50 & - \\
Sta & 150 & 0 a 136 & 50 a 170 \\
The01 & 150 & 0 a 121 & 136 a 150 \\
The02 & 180 & 0 a 116 & 121 a 150 \\
The03 & 150 & 0 a 120 & 116 a 180 \\
The04 & 65 & 0 a 65 & 120 a 150 \\
Zul & & & - \\
\hline
\end{tabular}




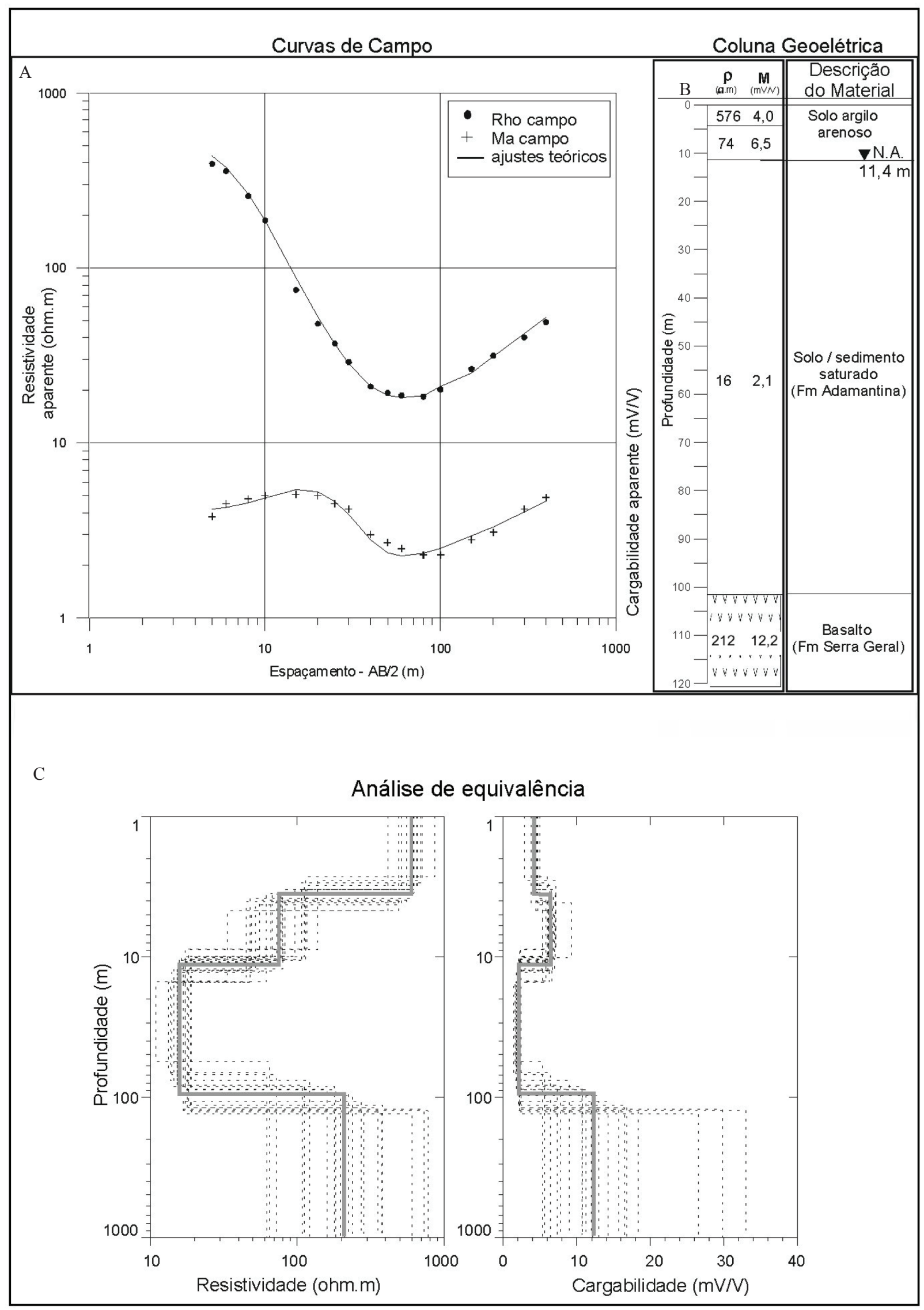

Figura 2 - Inversão $1 D$ da resistividade e cargabilidade (A), coluna geoelétrica (B) e análise de equivalência (C) da SEV AP02. 


\section{Perfil NS da Fazenda Aparecida}

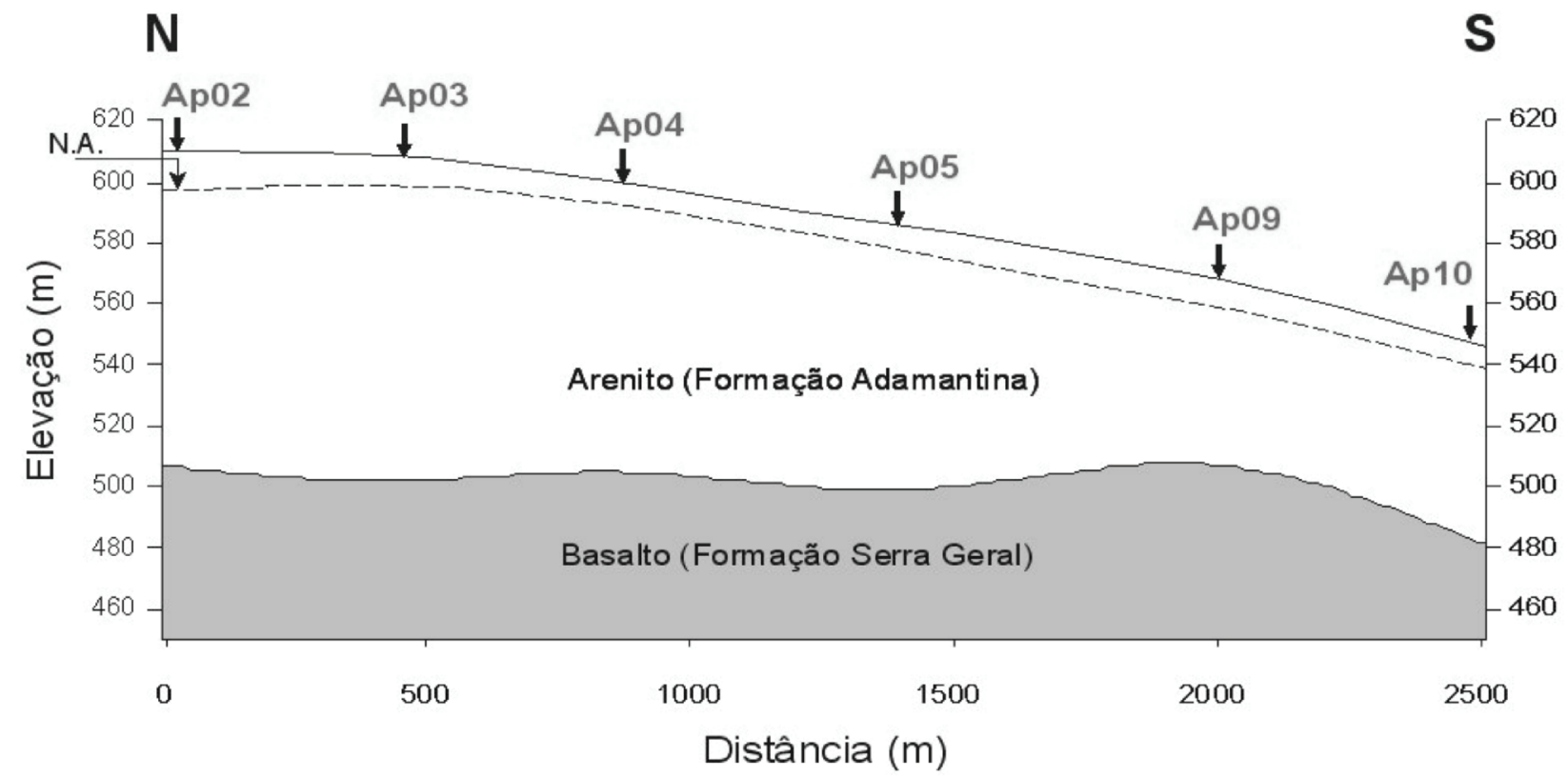

Figura 3 - Perfil N-S obtido nas vizinhanças da Fazenda Aparecida, no qual N.A. é o nível da água obtido com as SEVS.
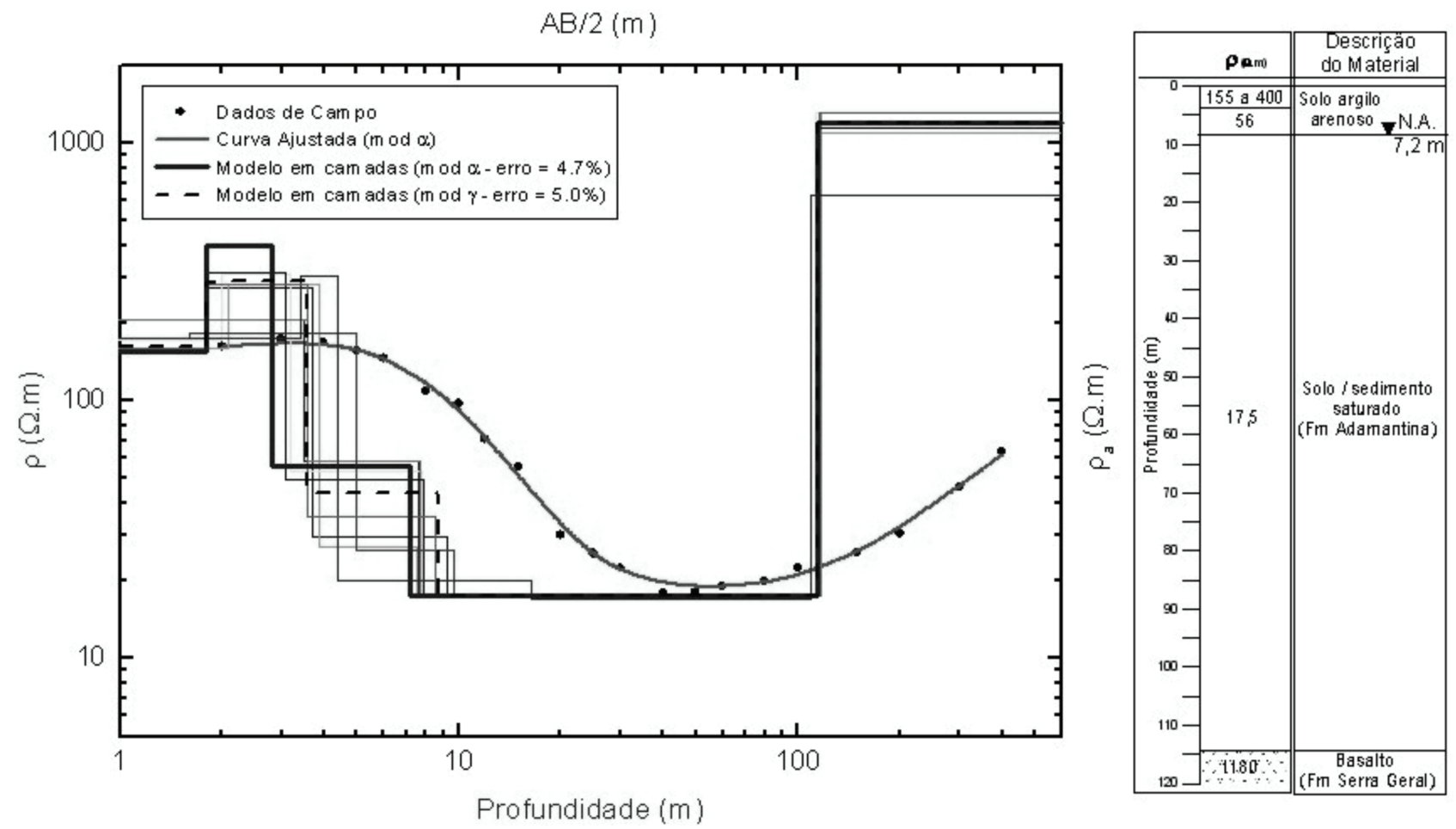

Figura 4-Modelos equivalentes para a SEV20. Modelo $\alpha=$ menor erro de ajuste; Modelo $\gamma=$ modelo médio. Interpretação baseada no modelo médio, à direita. 

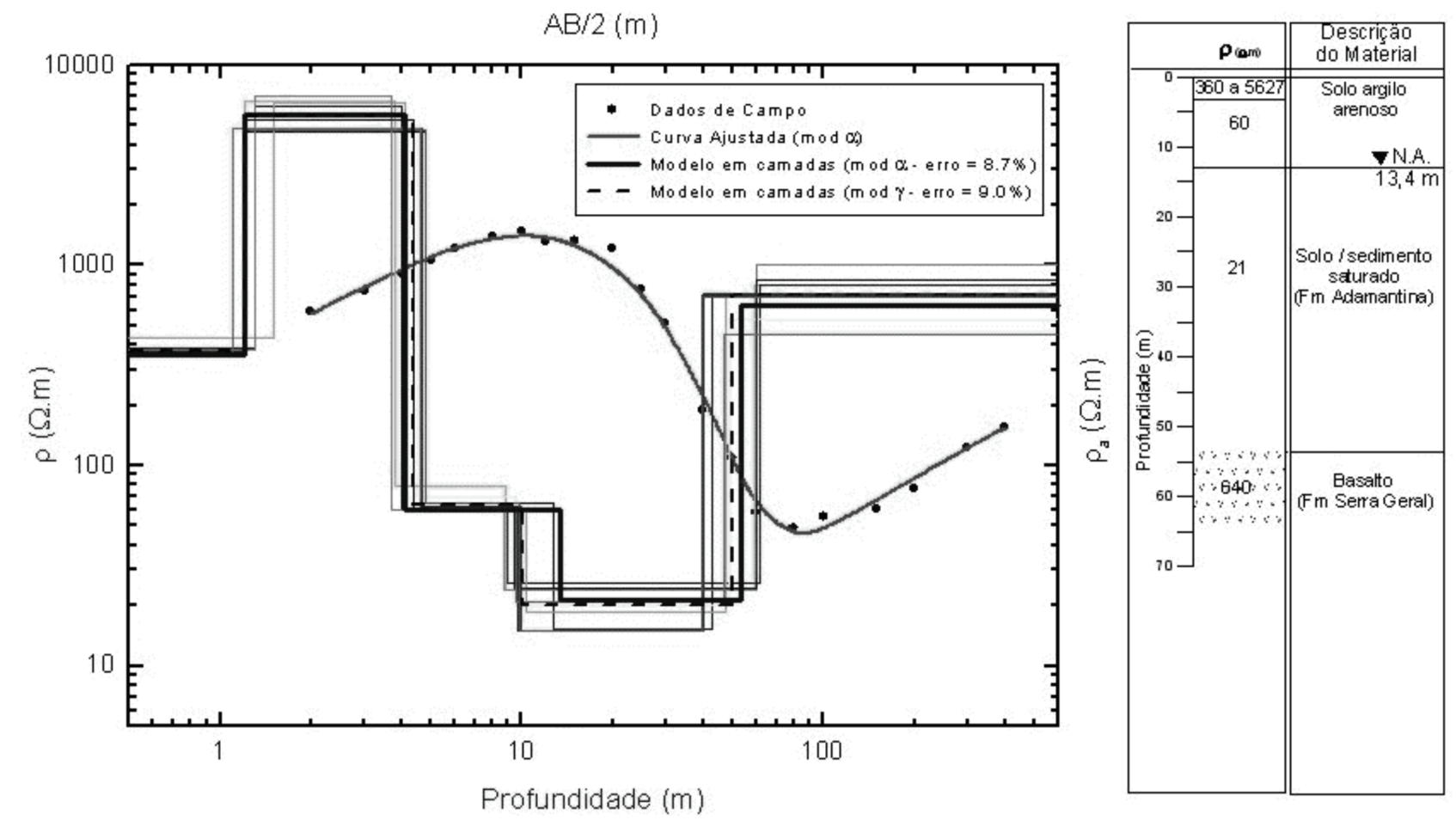

Figura 5 -Modelos equivalentes para a SEV18. Modelo $\alpha=$ menor erro de ajuste; Modelo $\gamma=$ modelo médio. Interpretação baseada no modelo médio, à direita.

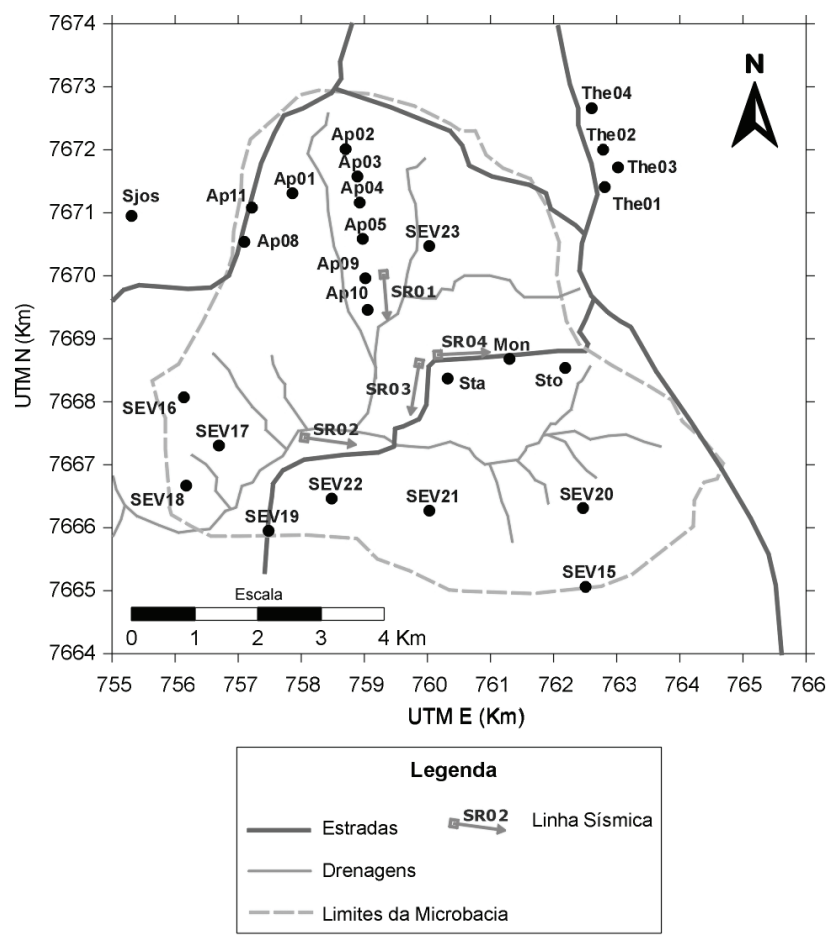

Figura 6-Localização dos ensaios de refração sísmica.

ilustram que não houve problemas com a marcação das primeiras chegadas das ondas refratadas, ou seja, os dados são de boa qualidade. Foram obtidos valores entre 3.500 e $4.000 \mathrm{~m} / \mathrm{s}$ para a velocidade da onda P no topo do basalto. Assim, esses valores foram empregados como critério para mapear o topo do basalto nas outras seções. Na Fig. 8 é apresentado um modelo tomográfico da linha SR03, no qual pode-se observar o maior gradiente de velocidade a partir de $55 \mathrm{~m}$ de profundidade (3.500 a $4.000 \mathrm{~m} / \mathrm{s})$, que é causado pelo topo do basalto. O poço mais próximo a essa seção está na Fazenda Santana, a cerca de $1 \mathrm{~km}$ de distância, em que o topo do basalto está a $50 \mathrm{~m}$ de profundidade.

O topo do basalto (Fig. 9) foi definido com as informações dos poços, das sondagens elétricas e das seções sísmicas. Pode-se observar que, no centro da área, existe um rebaixamento no topo do basalto. Entre as SEVs AP09 e AP10, essa superfície desce de 505 para $490 \mathrm{~m}$, continuando nesse nível no sentido Sul até a SEV22. A partir da SEV AP10 em direção Leste, o topo do basalto volta a ficar mais elevado, chegando a $520 \mathrm{~m}$ na SEV Sta, e volta a diminuir, de forma mais suave, na direção Sudeste, na qual estão as SEVs 20 e 15. Esse cenário sugere a presença de feições estruturais na área, as quais podem ter importância no condicionamento hidrogeológico local. O baixo existente entre AP09 e SEV22 apresenta orientação NE-SW, coincidindo com o vale do Rio Água Limpa. Tal estrutura parece estar condicionando essa drenagem.

Também foi possível elaborar o mapa de espessuras do arenito, apresentado na Fig. 10. Nesse mapa, pode-se observar que o arenito tem espessuras entre 55 m, na desembocadura do Rio Água Limpa, 


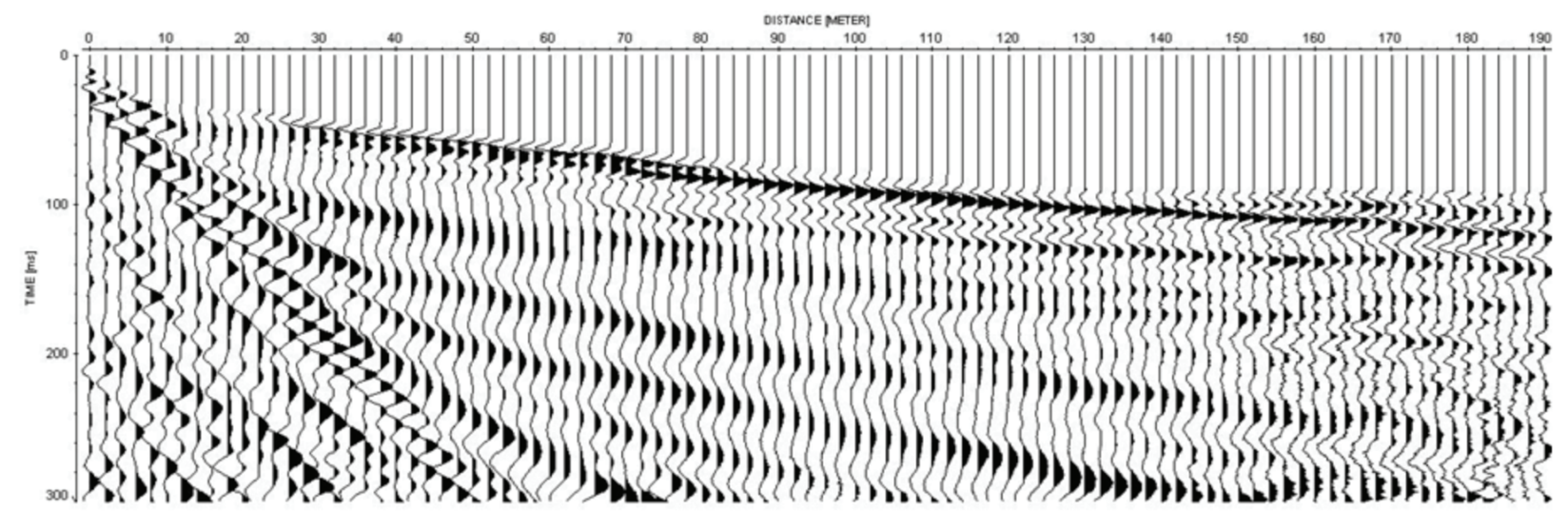

Tiro direto

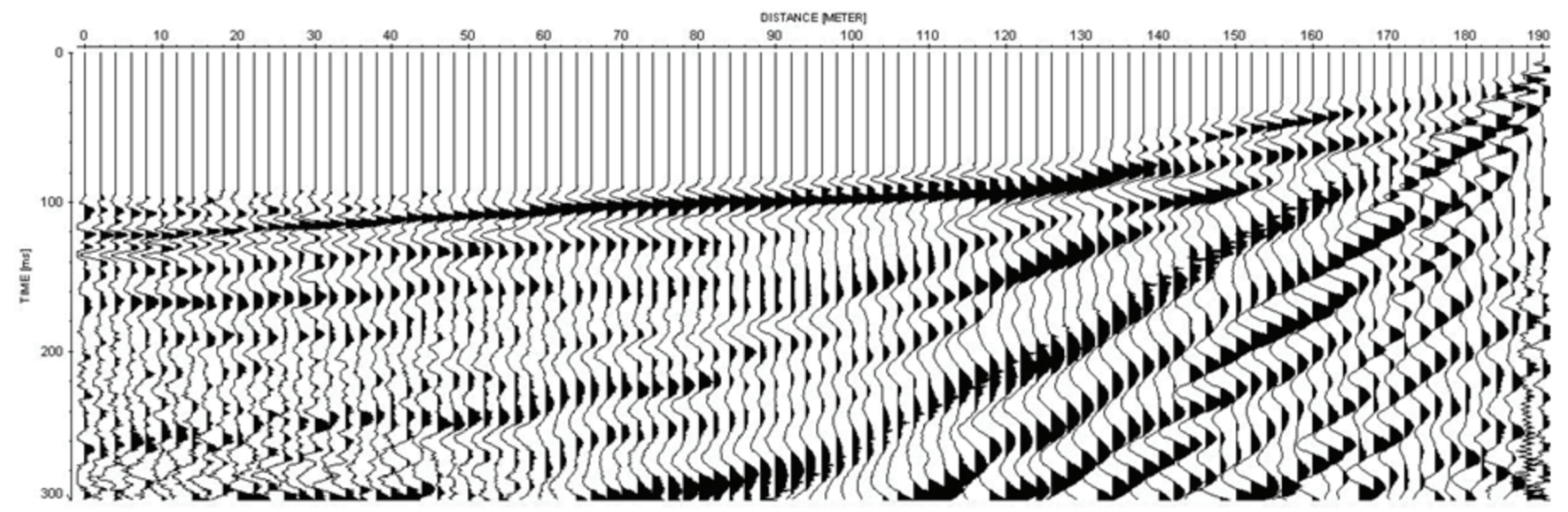

Tiro reverso

Figura 7 - Sismogramas dos tiros direto e reverso.

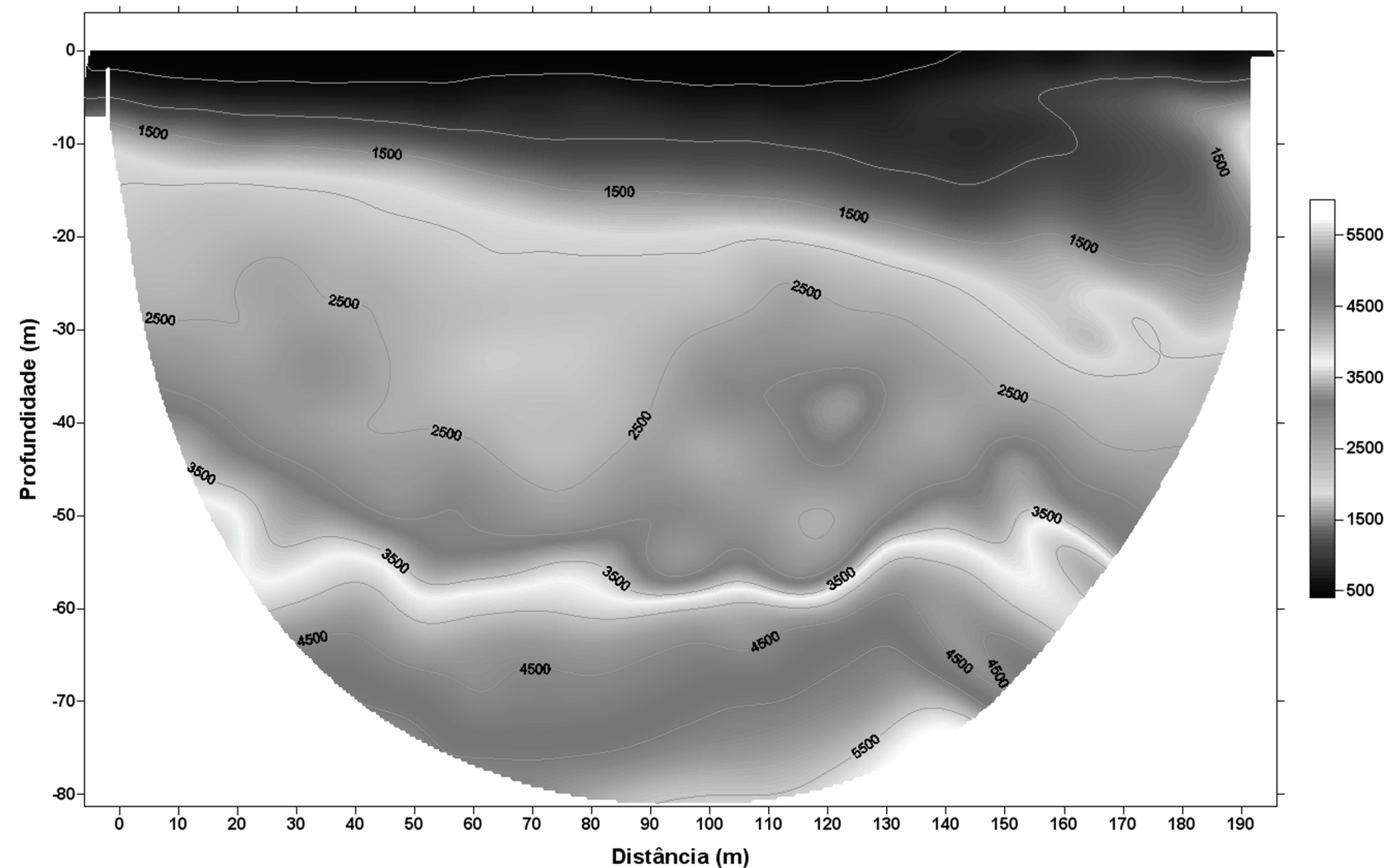

Figura 8 - Modelo tomográfico da Linha SR03. Observar o maior gradiente entre 3.500 e $4.000 \mathrm{~m} / \mathrm{s}$ devido ao topo do basalto. 


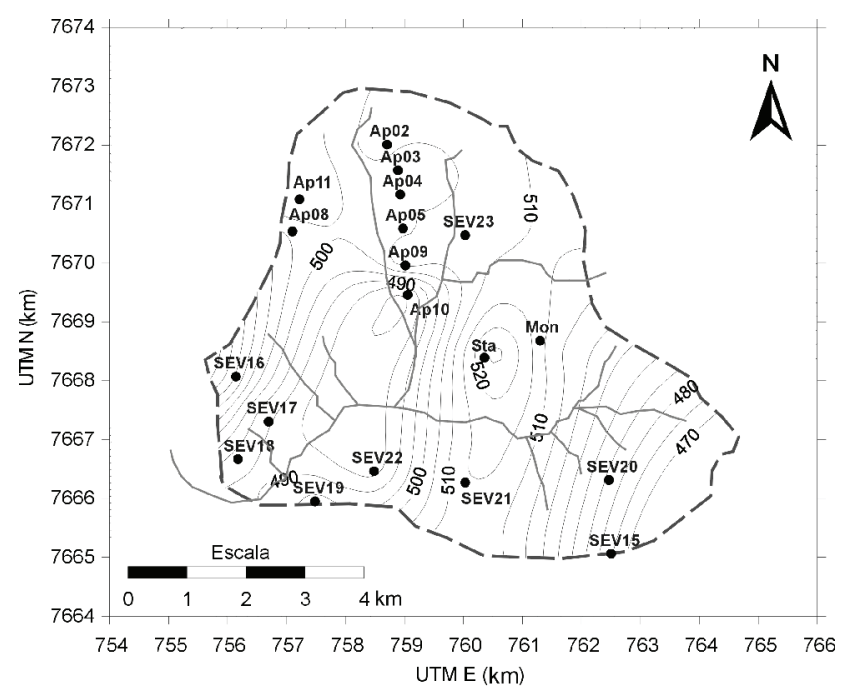

Figura 9-Mapa do topo do basalto (altitude em $\mathrm{m}$ ).

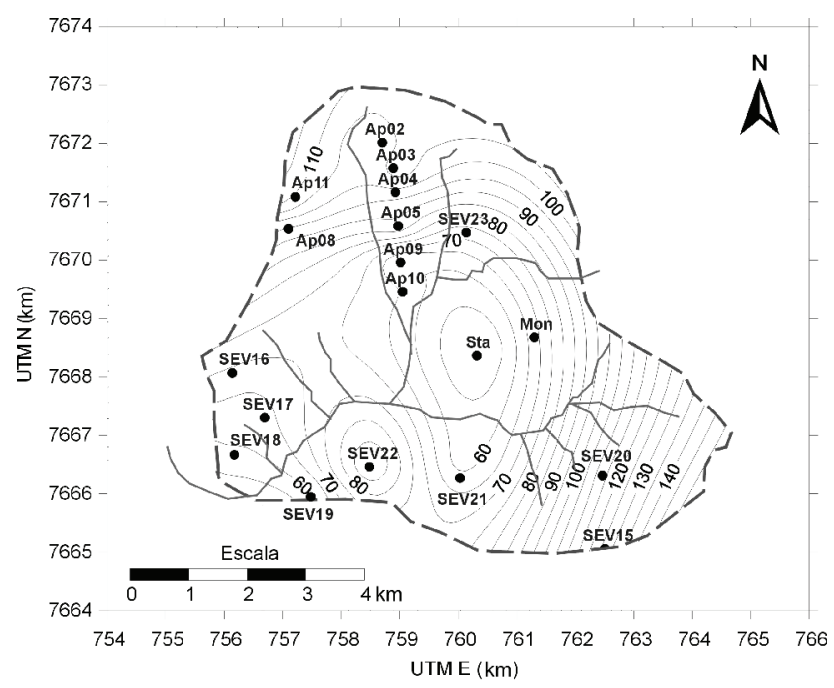

Figura 10 - Mapa de espessura do arenito (m).

até $140 \mathrm{~m}$, no extremo Sudeste da área. Embora o basalto seja mais profundo no vale do Rio Água Limpa, a topografia faz com que o arenito seja menos espesso. Na SEV Sta, o arenito também tem a menor espessura devido ao alto estrutural do basalto.

Estruturas No intuito de entender melhor a possível estruturação da área, foram realizados quatro ensaios de caminhamento elétrico dipolo-dipolo, com espaçamento de $50 \mathrm{~m}$, e cinco níveis de investigação em locais que possibilitaram a realização do ensaio. É importante lembrar que essa parte da investigação ficou bastante prejudicada, devido aos proprietários da Fazenda Aparecida não permitirem a aquisição de dados dentro de sua propriedade. Dessa forma, as linhas foram realizadas nas estradas nos entornos da referida propriedade, conforme localização mostrada na Fig. 11.

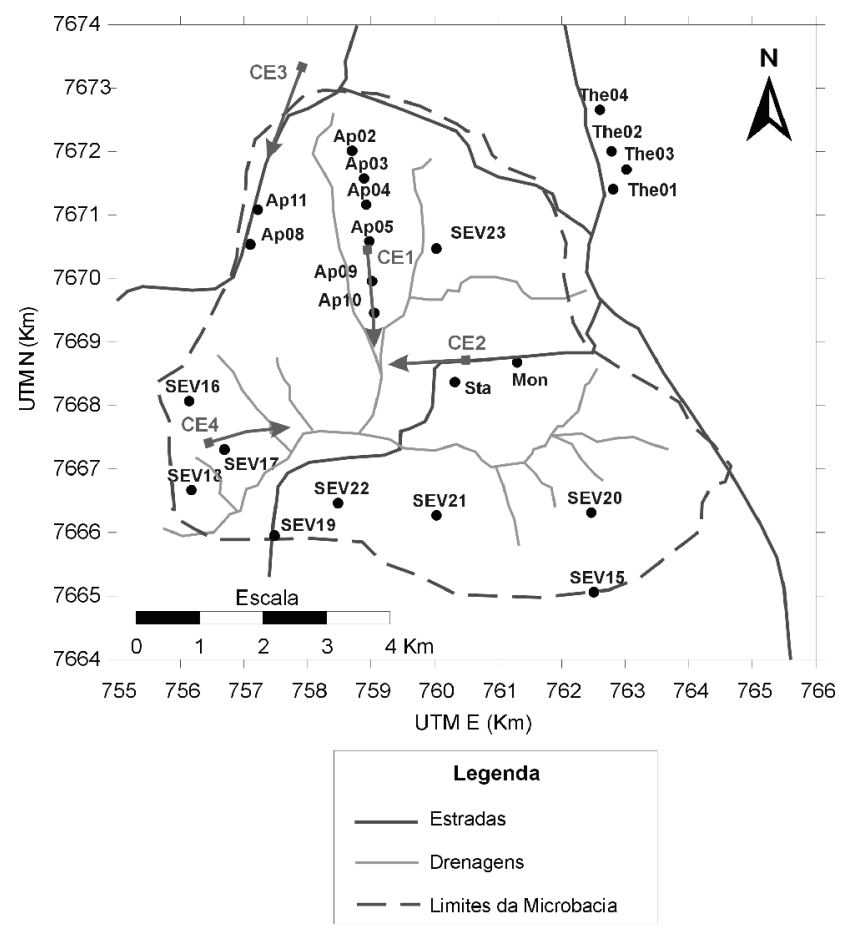

Figura 11-Localização dos ensaios de caminhamento, as setas indicam o sentido do ensaio.

A Linha CE1 foi realizada de Norte para Sul, passando ao lado dos poços AP09 e AP10, cujas informações auxiliaram na definição da posição do topo do basalto (Fig. 12). Nessa linha, pode-se observar o topo do basalto a cerca de $500 \mathrm{~m}$ de altitude mergulhando para Sul até a altitude de $480 \mathrm{~m}$, até que, imediatamente a Sul do AP10, ocorre uma brusca elevação do topo do basalto, feição interpretada como uma falha normal. Mais a Sul, na posição 1.100 m, aparece uma faixa mais condutora dentro do basalto, interpretada como uma possível zona de fraturas. $\mathrm{O}$ topo do basalto segue no perfil na altitude aproximada de $500 \mathrm{~m}$. Os poços AP10 e AP07, próximos desse local, apresentam vazões anômalas, de 165 e 190 m $/ \mathrm{h}$ (muito mais altas que os demais poços da Fazenda Aparecida, os quais apresentam em média vazões de $50 \mathrm{~m}^{3} / \mathrm{h}$ ). Essas vazões anômalas podem ter explicação na presença de tais estruturas, aumentando localmente a porosidade secundária.

Nas demais linhas de CE não foram observados indícios de falhamentos, apenas um aumento da resistividade devido ao topo do basalto. Em todos os perfis de $\mathrm{CE}$, o arenito saturado foi identificado pelas baixas resistividades. É possível verificar algumas variações laterais de resistividade nessa unidade, o que pode estar associado a variações composicionais (variações nos teores de argila) ou texturais. 


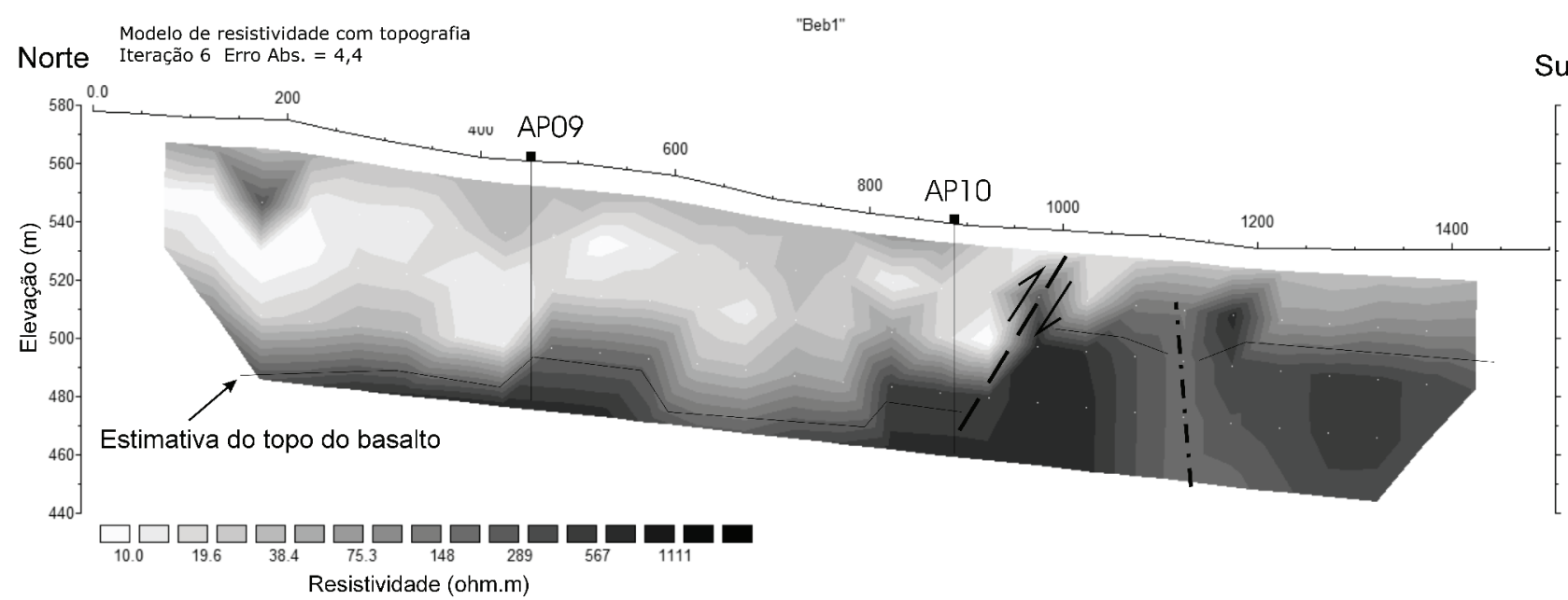

Figura 12 - Perfil CE1 realizado nos fundos da Fazenda Aparecida com a devida correção topográfica. AP09 e AP10 são os poços perfurados.
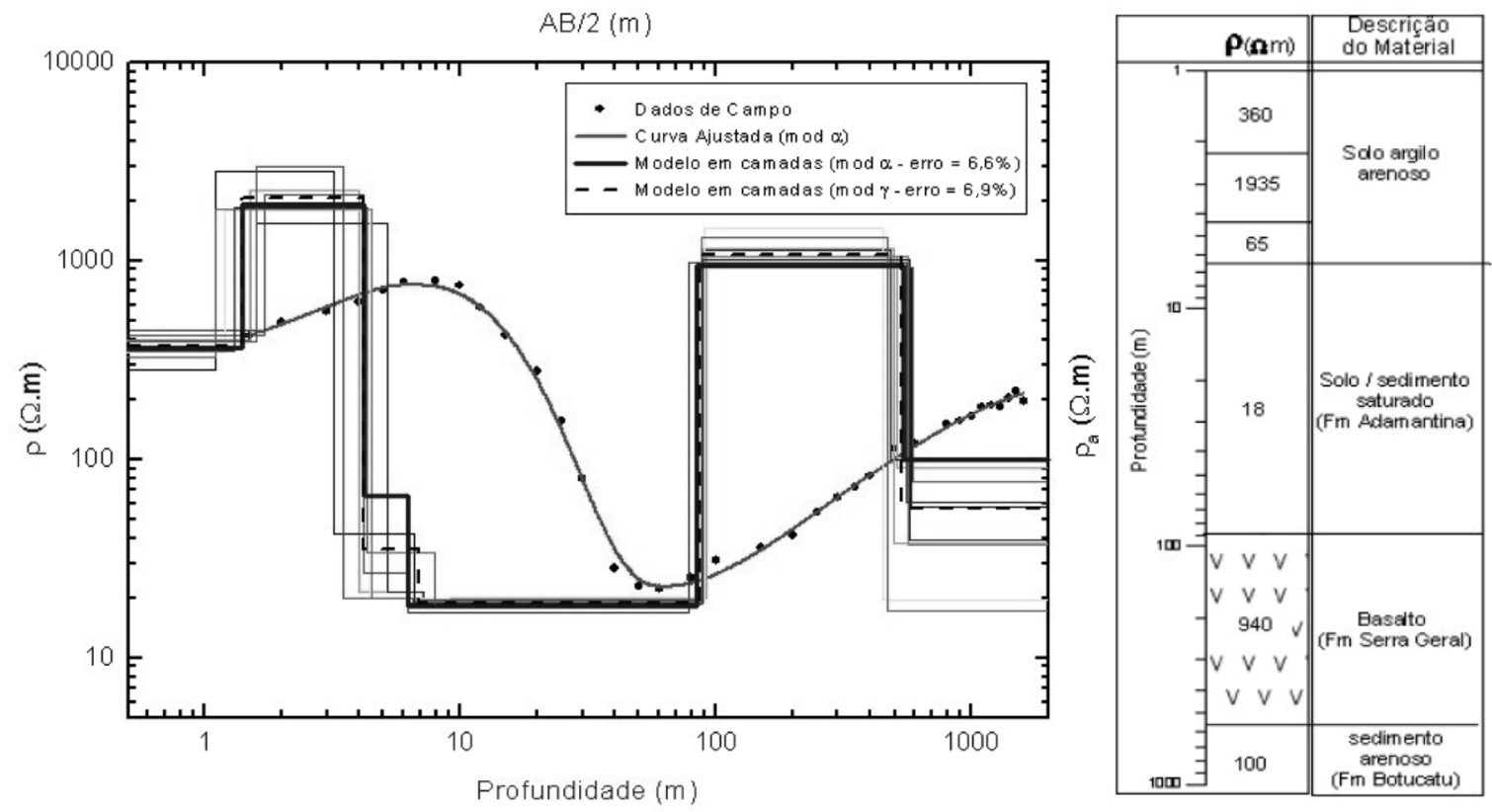

Figura 13 - Inversão $1 D$ da resistividade (A) e coluna geoelétrica (B) da SEV longa (AB/2 de 1.600 m), realizada próximo ao Poço AP05.

Como citado, os dados dos poços, fornecidos pelo DAEE, mostram que muitos deles exploram também o aquífero basalto fraturado. Muitos desses dados mostram poços que atravessam fraturas horizontais e zonas interderrames de basalto vesicular, apresentando vazões anormalmente altas.

Dessa forma, foram realizadas SEVs com aberturas maiores $(\mathrm{AB} / 2$ de 1.300 a $1.600 \mathrm{~m})$ e sondagens TDEM, com o objetivo de estudar possíveis variações de resistividade dentro do basalto, relacionáveis a zonas interderrames. Foram realizadas três SEVs longas: uma próxima ao poço AP05, outra próxima ao poço da
Estância Monideni e outra na Fazenda Zulmira, próxima da SEV17 (Fig. 1). Os resultados não permitiram identificar zonas de fratura e/ou interderrame dentro do basalto, mas apenas o topo e a base do basalto, no contato com a Formação Botucatu, como pode ser observado na Fig. 13, que apresenta os resultados da SEV longa realizada próxima ao poço AP05. Pode-se observar que o final da curva, em razão da grande abertura, não é tão bem definido quanto para as camadas sobrejacentes. Para sustentar essa interpretação, são usados os resultados das sondagens TDEM, os quais definem bem o condutor profundo, que caracteriza o Arenito Botucatu (Fig. 14). 

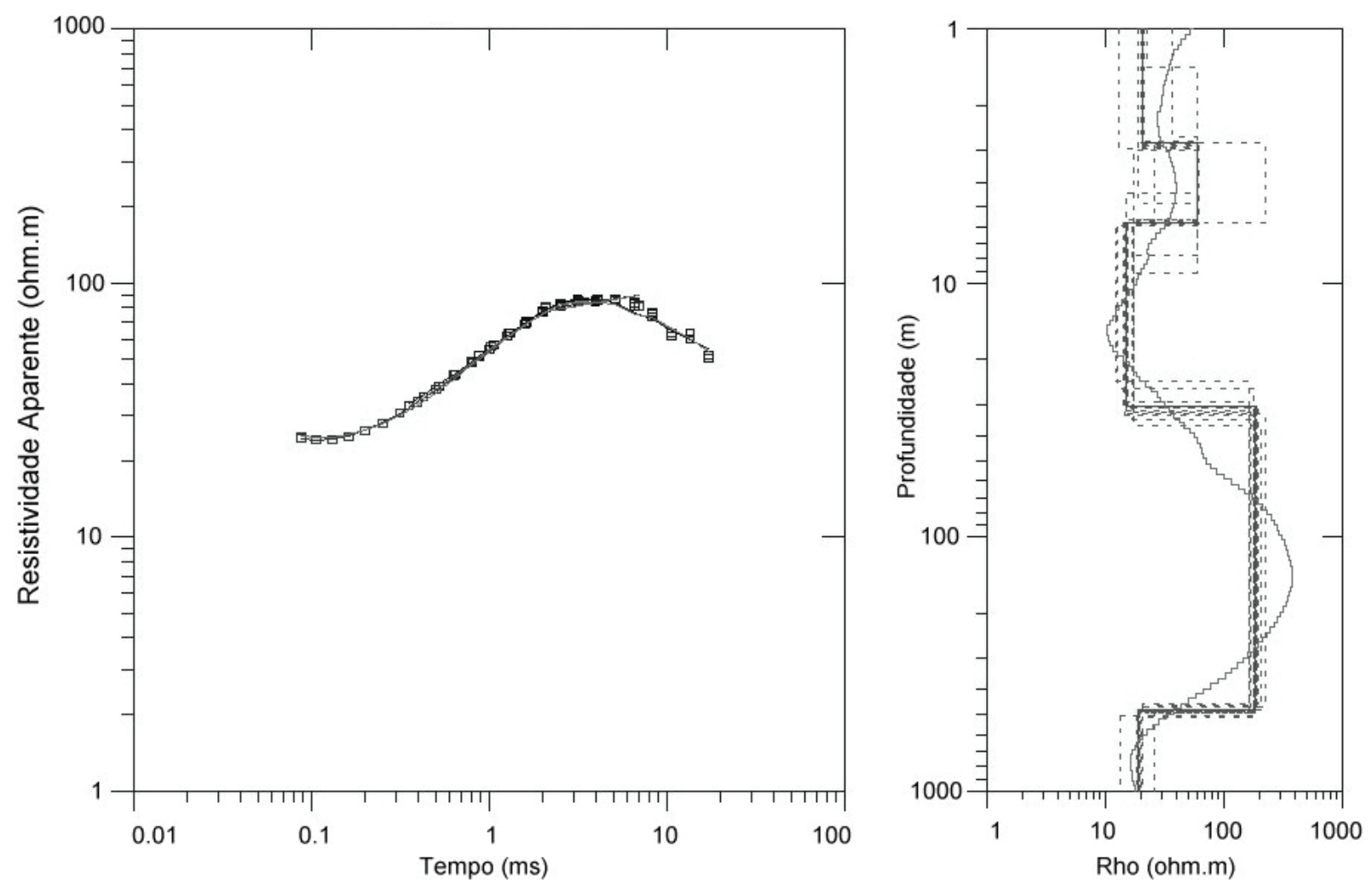

Figura 14 - Inversão $1 D$ da sondagem TDEM realizada próximo ao Poço AP09. O condutor que aparece a partir de $500 \mathrm{~m}$ de profundidade caracteriza a Formação Botucatu.

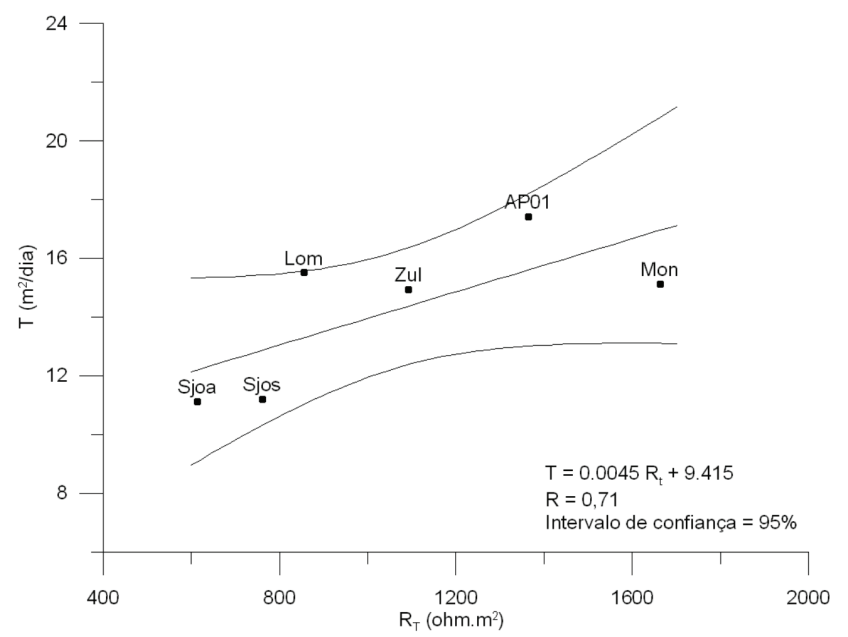

Figura 15 - Gráfico RT x T obtido para os dados dos poços perfurados no arenito.

Essa sondagem longa apresentada na Fig. 13 foi executada próxima do Poço Ap09, e pode-se observar a camada mais resistiva, que caracteriza o basalto, até a profundidade de $500 \mathrm{~m}$. Não foi possível observar, também nas sondagens TDEM, zonas condutoras dentro do basalto, as quais pudessem identificar fraturas e/ ou interderrames. Essas sondagens foram

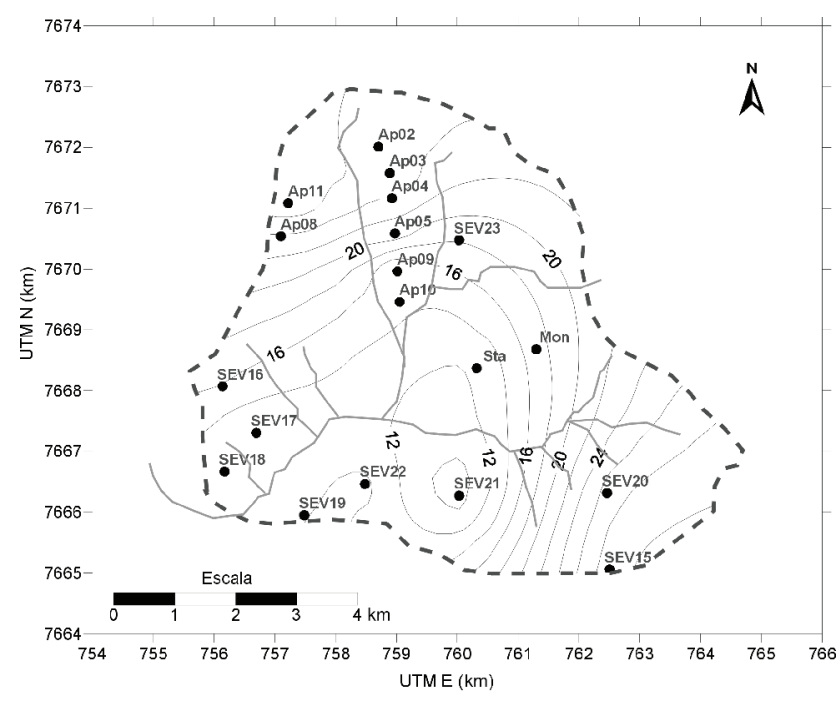

Figura 16-Mapa da transmissividade estimada do arenito.

executadas na mesma região, próximas dos poços AP05, AP09 e AP10, em razão de ser a zona de maior atividade sísmica (Assumpção \& Yamabe 2005), na qual espera-se que existam mais estruturas dentro do basalto. Mesmo na sondagem TDEM realizada próximo ao poço 10 , na zona de anomalia de baixa resistividade identificada no caminhamento elétrico, não 


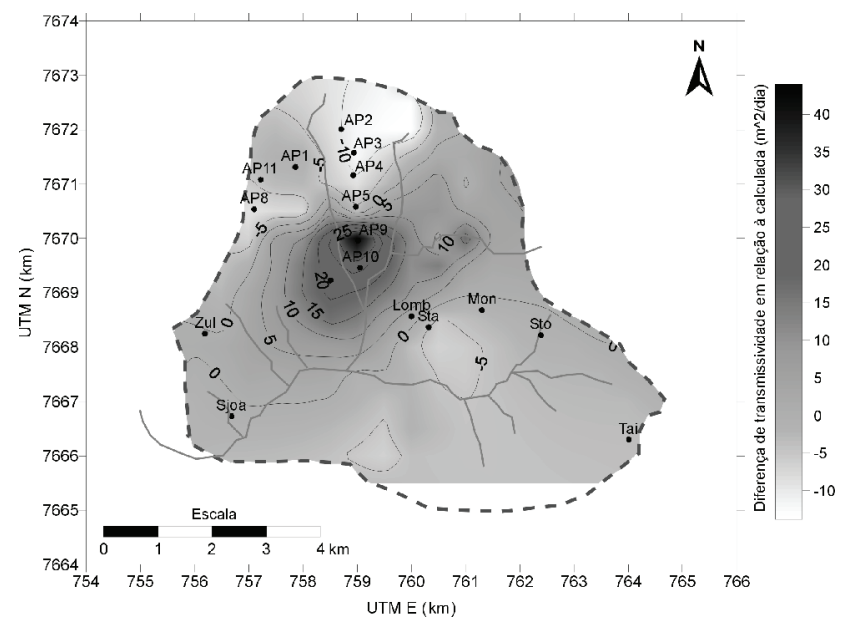

Figura 17 - Mapa da diferença de transmissividade obtida dos testes de vazão em relação à transmissividade calculada do arenito.

foram detectadas possíveis estruturas ou zonas interderrames no basalto. Uma explicação para o fato de as sondagens TDEM não identificarem a zona de fratura observada no caminhamento elétrico é que sua interpretação fornece um modelo $1 \mathrm{D}$, não permitindo a visualização de uma estrutura com alto ângulo de mergulho. Pode ser interessante, em trabalhos futuros, realizar mais sondagens TDEM em outros locais para verificar se estas detectam tais estruturas.

\section{Correlação entre resistência transversal e transmissi-} vidade A resistência transversal da área em apreço foi obtida das SEVs, multiplicando-se a resistividade pela espessura saturada do arenito. O procedimento para se obter a transmissividade é por meio dos testes de produção de poços. Da análise dos dados de poços disponíveis, notou-se que a maioria deles explorava também o Aquífero Serra Geral. Esse fato dificultou a correlação entre $\mathrm{R}_{\mathrm{T}} \mathrm{e}$, pois muitos dos poços perfurados no basalto encontraram fraturas (o que aumentou muito a transmissividade no teste de produção) e outros encontraram o basalto sem fraturas (o que diminuiu a transmissividade). Como essa relação é válida apenas para aquíferos porosos, foi necessária uma revisão dos relatórios para verificação dos poços que exploravam somente o aquífero poroso. Dessa forma, foram separados os poços perfurados somente no arenito que estavam dentro da microbacia (Fig. 1), e mais o poço da Fazenda São José, próximo da borda Oeste da microbacia, o que resultou em um número reduzido de poços (apenas seis).

A despeito do reduzido número de poços, a correlação obtida para um intervalo de confiança de 95\% mostrou um coeficiente de 0,71 para o ajuste da regressão linear (Fig. 15). Tal relação pode ser utilizada para previsão da transmissividade dentro da microbacia, inserindo-se o valor de $\mathrm{R}_{\mathrm{T}}$ de cada sondagem elétrica na equação. O resultado é apresentado na Fig. 16, na qual observa-se a variação de transmissividade esperada para o arenito. Esse mapa mostra que, na parte Centro-sul da microbacia, ocorrem os menores valores de transmissividade, em razão da menor espessura do arenito. Da mesma forma, nas regiões mais altas, em que a camada de arenito é mais espessa, aparecem os maiores valores.

Pode-se usar a estimativa de transmissividade do arenito para avaliar as regiões com maior ou menor influência da água proveniente do basalto nos poços. Na Fig. 17, apresenta-se o mapa da diferença de transmissividade obtida dos testes de vazão (para os poços que perfuraram o basalto) em relação à transmissividade estimada para o arenito. Esse mapa mostra que existe uma zona (na região dos poços AP09 e AP10) em que as transmissividades sofrem considerável influência das estruturas existentes no basalto. Essa região é a mesma que apresenta uma feição interpretada como falha e/ou fratura nos caminhamentos elétricos. Como alguns poços atingiram zonas fraturadas no basalto e outros não atingiram, os valores de transmissividade obtidos dos testes de vazão foram influenciados ora para mais (por exemplo, o poço AP09, que foi perfurado $96 \mathrm{~m}$ no basalto, apresentando fraturas e vesículas, transmissividade de $60,9 \mathrm{~m}^{2} /$ dia) e ora para menos (poço AP05, perfurado $94 \mathrm{~m}$ no basalto, que apresenta fraturas, mas transmissividades de $1,5 \mathrm{~m}^{2} /$ dia). Se considerar-se que estes poços estão apenas $500 \mathrm{~m}$ distantes um do outro, pode-se concluir que, devido ao comportamento aleatório das estruturas dentro do basalto, a utilização destes mapas auxilia no estudo do aquífero fraturado. É possível observar que o Poço AP07, localizado dentro da Fazenda Aparecida, em que não foi permitido executar sondagem geofísica, está dentro da zona de transmissividades anormalmente altas. No teste de vazão fornecido pela DAAE, este poço realmente apresentou transmissividade alta, de $32,2 \mathrm{~m}^{2} /$ dia.

CONCLUSÕES O objetivo principal deste trabalho foi utilizar a integração das informações obtidas por métodos geofísicos com informações hidrogeológicas dos poços existentes, para um conhecimento mais aprofundado das características hidrogeológicas dos aquíferos Adamantina e Serra Geral, na região de Bebedouro, em São Paulo. Os métodos utilizados mostraram eficiência no estudo da geometria do 
aquífero, com destaque para a eletrorresistividade e a sísmica. Foi possível estimar a espessura do arenito, a profundidade da zona saturada e o topo do basalto.

A base do basalto em contato com a Formação Botucatu foi identificada pelas SEVs com maiores aberturas e pelas sondagens TDEM. As profundidades são consistentes com informações de um poço profundo existente na área.

Os caminhamentos elétricos, além de mapear a morfologia do topo do basalto, auxiliaram na identificação das possíveis falhas e zonas de fraturas no perfil CE01, o que é compatível com desníveis observados no mapa do topo do basalto. Além disso, as vazões anômalas nos poços próximos também são compatíveis com a presença dessas estruturas.

A correlação entre $R_{T}$ e $T$ em um primeiro momento encontrou limitações devido à interação hidráulica entre o arenito e o basalto. Porém, utilizando-se somente alguns poços que não exploram água do basalto, foi possível estabelecer essa correlação. Dessa forma, pode-se usar essa correlação para previsão de transmissividade em novos locais dentro da microbacia.

Esse conjunto de informações pode ser usado para auxiliar no gerenciamento do aquífero, tanto sob o ponto de vista de exploração como de preservação. Por meio das transmissividades estimadas, pode-se calcular a condutividade hidráulica e suas variações dentro da microbacia. Isso pode ser utilizado em processos de modelagem de aquífero, com a vantagem de se utilizar apenas a condutividade hidráulica da camada de interesse, ou seja, arenito ou basalto.

AGRADECIMENTOS Os autores agradecem ao apoio financeiro dado pelo Conselho Nacional de Desenvolvimento Científico e Tecnológico (CNPq) pela bolsa de Doutorado e Auxílio à Pesquisa (processo 471516/2006-6) e ao Departamento de Geofísica do Instituto de Astronomia, Geofísica e Ciências Atmosféricas da Universidade de São Paulo (USP), pela infraestrutura.

\section{Referências}

Assumpção M.S. \& Yamabe T.H. 2005. Atividade sísmica no distrito de Andes, Bebedouro, e a possível relação com perfuração de poços tubulares. Relatório Interno IAG, Universidade de São Paulo, São Paulo, 14 p. Disponível em: Acesso em 20/07/2011.

Departamento de Águas e Energia Elétrica (DAEE). 1976. Estudo de Águas Subterrâneas das Regiões Administrativas 7, 8 e 9 - Bauru, São José do Rio Preto e Araçatuba. São Paulo, v. 1, 2 e 3.

Fernandes L.A. 1992. A cobertura cretácea suprabasáltica no Paraná e Pontal do Paranapanema (SP): os grupos Bauru e Caiuá. Dissertação de Mestrado, Instituto de Geociências, Universidade de São Paulo, São Paulo, 129 p.

Fernandes L.A. \& Coimbra A.M. 2000. Revisão estratigráfica da parte oriental da Bacia Bauru (Neocretáceo). Revista Brasileira de Geociências, 30(4):717-728.

Figueiredo J.O., Stuchi L.C.D., Teófilo Sobrinho J., Laranjeira F.F., Pio R.M., Sempionato J.R. 2002. Porta-enxertos para a lima-ácida-'tahiti' na região de Bebedouro, SP. Revista Brasileira de Fruticultura, 24(1):155-159.

Frohlich R.K. \& Kelly W.E. 1985. The relation between hydraulic transmissivity and transverse resistance in a complicated aquifer of glacial outwash deposits. Journal of Hydrology, 79:215-229.

Instituto de Pesquisas Tecnológicas do Estado de São Paulo (IPT). 1981. Mapa Geológico do Estado de São Paulo. São Paulo, mapa geológico, escala 1:500.000.
Instituto de Pesquisas Tecnológicas do Estado de São Paulo (IPT). 2001. Diagnóstico da situação atual dos Recursos Hídricos e estabelecimento de diretrizes técnicas para a elaboração do Plano da Bacia Hidrográfica do Turvo/Grande. Relatório IPT, n. 40.515, São Paulo, v. 1, 339 p.

Intelligent Resources. 2006. Rayfract Seismic Refraction \& Crosshole Tomography Manual. Intelligent Resources Inc., Canada, 18 p.

Interpex Limited. 1993. RESIX-IP v. 2.0 - DC Resistivity and Induced Polarization Data Interpretation Software. User's Manual. Interpex Limited, Golden, Colorado, USA, $108 \mathrm{p}$.

Interpex Limited. 2007. IX1D v. 3.0 Instruction Manual. Interpex Limited, Golden, Colorado, USA, $131 \mathrm{p}$.

Kelly W.E. 1977. Geoelectric Sounding for estimating aquifer hydraulic conductivity. Ground Water, 15(6):420-425.

Kosinski W.K. \& Kelly W.E. 1981. Geoelectric soundings for predicting aquifer properties. Ground Water, 19(2):163-171.

Lecomte I., Gjoystdal H., Dahle A., Pedersen O.C. 2000. Improving modeling and inversion in refraction seismics with a first-order Eikonal solver. Geophysical Prospecting, 48:437-454.

Loke M.H. 2003. RES2DINV - Rapid 2d Resistivity \& IP Inversion Using The Least-Square Method Geoelectrical Imaging 2-D \& 3-D. Geotomo Software, Penang, Malaysia, 129 p. 
Maillet R. 1947. The fundamental equations of electrical prospecting. Geophysics, 12(4):529-556.

Mazac O., Kelly W.E., Landa I. 1985. A hydrogeophysical model for relations between electrical and hydraulic properties of aquifers. Journal of Hydrology, 79:1-19.

McNeill J.D. 1990. Use of electromagnetic methods for groundwater studies. Geotechnical and Environmental Geophysics, ed: S.H.Ward, SEG, Investigations in Geophysics, 5(1):191-218.

Niwas S. \& Singhal D.C. 1981. Estimation aquifer transmissivity from Dar Zarrouk parameters in porous media. Journal of Hydrology, 50:393-399.

Orellana E. 1972. Prospeccion Geoelectrica en Corriente Continua. Paraninfo, Madrid, 523 p.

Osella A., Favetto A., Martinelli P., Cernadas D. 1999. Electrical imaging of an alluvial aquifer at the Antinaco-Los Colorados tectonic valley in the Sierras Pampeanas, Argentina. Journal of Applied Geophysics, 41:359-368.

Rubin Y. \& Hubbard S.S. 2005. Hydrogeophysics. Water Science and Technology Library Series, Springer, v. 50, 523 p.

Silva F.P., Chang H.K., Chang M.R.C. 2005. Hidroestratigrafia do Grupo Bauru (k) no Estado de São Paulo. Águas Subterrâneas, 19(2):19-36.
Soares P.C., Landim P.M.B., Fulfaro V.J., Neto A.F.S. 1980. Ensaio de caracterização estratigráfica do cretáceo no Estado de São Paulo: Grupo Bauru. Revista Brasileira de Geociências, 10(3):170-185.

Sumner J.S. 1976. Principles of Induced Polarization for Geophysical Exploration. Elsevier Scientific Publishing Co., Amsterdan, 227 p.

Telford W.M., Geldart L.P., Sheriff R.E., Keys D.A. 1990. Applied Geophysics. Cambridge University Press, New York, 860 p.

Unesco. 2003. Water for people - Water for life - The United Nations World Water Development Report. UNESCO Publishing, Paris, 688 p.

Vouillamoz J.M., Chatenoux B., Mathieu F., Baltassat J.M., Legchenko A. 2007. Efficiency of joint use of MRS and VES to characterize coastal aquifer in Myanmar. Journal of Applied Geophysics, 61:142-154.

Watanabe T., Matsuoka T., Ashida Y. 1999. Seismic traveltime tomography using Fresnel volume approach. In: 69th SEG Annual Meeting, Expanded Abstracts, p. 1402-1405.

Manuscrito ID 22513

Recebido em: 10/08/2011

Aprovado em: 01/06/2012 